\title{
Migration of Mn-rich fluids through normal faults and fine-grained terrigenous sediments during early development of the Neogene Vallès-Penedès half-graben (NE Spain)
}

\author{
A. TRAVÉ ${ }^{1}$, E. ROCA ${ }^{2}$, E. PlayÀ ${ }^{1}$, D. PARCERISA ${ }^{3}$, D. GÓMEZ-GRAS ${ }^{4}$ \\ AND J. D. MARTÍN-MARTÍN ${ }^{1}$ \\ ${ }^{I}$ Departament de Geoquímica, Petrologia i Prospecció Geologica, Facultat de Geologia, Universitat de Barcelona, Barcelona, \\ Spain; ${ }^{2}$ Departament de Geodinàmica $i$ Geofisica, Facultat de Geologia, Universitat de Barcelona, Barcelona, Spain; \\ ${ }^{3}$ Dpt. d'Enginyeria Minera i Recursos Naturals, Edifici MN2, EPSEM, UPC Av. Bases de Manresa 61-73, Manresa, Spain; \\ ${ }^{4}$ Departament de Geologia, Facultat de Ciències, Universitat Autònoma de Barcelona, Bellaterra, Spain
}

\begin{abstract}
The Miocene siliciclastic sediments infilling the Vallès-Penedès half-graben are affected by two sets of structures developed during the extensional tectonics that created the basin. The first set, represented by extension fractures infilled with mud and sands, is attributed to seismically induced liquefaction. The second set, represented by normal faults, corresponds to a high-permeability horsetail extensional fracture mesh developed near the surface in the hanging walls of normal faults. The incremental character of the vein-fills indicates episodic changes in the tectonic stress state and fault zone permeability. Two episodes of fluid migration are recorded. The first episode occurred prior to consolidation and lithification when shallow burial conditions allowed oxidizing meteoric waters to flow horizontally through the more porous and permeable sandy layers. Development of clastic dikes allowed local upward flow and dewatering of the sandy beds. Liquefaction and expulsion of fluids were probably driven by seismic shaking. During the first episode of fluid migration there was no cementation of the sandstone or within the fractures, probably because little fluid was mobilized by the predominantly compaction-driven flow regime. The second episode of fluid migration occurred synchronously with normal fault development, during which time the faults acted as fluid conduits. Fluids enriched in manganese, probably leached from local manganese oxyhydroxides soon after sedimentation, moved laterally and produced cementation in the sandstone layers, eventually arriving at the more porous and permeable fault pathways that connected compartments of different porosities and permeabilities. Carbonate probably precipitated in fractures saturated with meteoric water near the ground surface at a transitional redox potential. Once the faults became occluded by calcite cement, shortly after fault development, they became barriers to both vertical and horizontal fluid flow.
\end{abstract}

Key words: calcite cement, fluid flow, manganese, Miocene, normal fault, siliciclastic sediment

Received 28 April 2009; accepted 23 July 2009

Corresponding author: Anna Travé, Departament de Geoquímica, Petrologia i Prospecció Geològica, Facultat de Geologia, Universitat de Barcelona, Martí i Franqués, s/n, 08028 Barcelona, Spain.

Email: atrave@ub.edu. Tel: +34 93 4021416. Fax: +34 934021340.

Geofluids (2009) 9, 303-320

\section{INTRODUCTION}

Many hydrocarbon-bearing reservoirs occur in siliciclastic facies within extensional basins (Badley et al. 1988; Antonellini \& Aydin 1994, 1995; Matthai et al. 1998; Ottesen Ellevset et al. 1998) where fractures have served as pathways for migration of aqueous fluids and/or hydrocarbons. These fractures are commonly cemented by quartz and carbonate minerals, which record valuable information about the fluids from which they precipitated and the reservoirs through which they flowed.

This paper deals with calcite cements filling fractures in Miocene (Burdigalian) syn-rift alluvial sandstones and lutites located in the central part of the Neogene VallèsPenedès half-graben (NE Spain). These calcite cements contain anomalously high $\mathrm{Mn}$ concentrations of up to 29325 p.p.m. ( $\approx 3 \%$ by mass). Although Mn can theoretically replace up to $40 \%$ of the mass of the calcite structure 
(Berry \& Mason 1959), Mn concentrations in carbonates as high as those from this study have only been reported previously from the Precambrian Fe/Mn-rich formations of the Kalahari manganese field in South Africa (Tsikos et al. 2003), in complex authigenic carbonates in the Oregon and Barbados convergent margins (Ritger et al. 1987; Vrolijk \& Sheppard 1991; Labaume et al. 1997; Sample \& Reid 1998) and in shallowly buried organic-rich sediments (Pedersen \& Price 1982; Mount \& Cohen 1984; Tasse \& Hesse 1984; Curtis et al. 1986; Polgári et al. 1991; Pratt et al. 1991; Hendry 1993).

Based on structural analysis of the fractures, and the petrology and geochemical composition of the calcite cements filling the fractures, we aim to determine the composition and origin of the fluids that circulated through the fractures, the relative timing of fluid flow and its relationship to deformation, the source of $\mathrm{Mn}$ and the environmental conditions during precipitation. The geochemistry of the calcite cements yields information on fluid composition and origin. Detailed petrology of the veins allows us to establish the relation between deformation, fluid migration and the timing of fluid flow. Finally, integration of all these data within the specific geological setting of the Vallès-Penedès half-graben constrains the source of $\mathrm{Mn}$ and the environmental conditions of calcite precipitation. Thus, the goal of this paper is to generate further insights into the behaviour of fluids during the early evolution of an extensional basin, continuing work begun by Travé et al. (1998) on the horsts bordering the basin, by focusing on calcite cements in fractures in proximal conglomerates (Travé \& Calvet 2001) and in sandstones within the basin (Parcerisa et al. 2005, 2006).

\section{GEOLOGICAL SETTING}

The Vallès-Penedès half-graben is part of the Catalan Coastal Ranges. The Catalan Coastal Ranges are situated in the north-westernmost part of the Valencia Trough, a NE-SW-oriented basin located between the Iberian Peninsula and the Balearic Promontory. These ranges display a well-developed horst-and graben structure acquired during the late Oligocene to early Miocene opening of the northwestern Mediterranean Sea (Roca \& Guimerà 1992; Roca et al. 1999). NE-SW and ENE-WSW-trending extensional faults split the central part of the Catalan Coastal Ranges into four major blocks: the Prelitoral range, the VallèsPenedès half-graben, the Montnegre-Garraf horst and the offshore Barcelona graben. The two major extensional faults are the Vallès-Penedès and Barcelona normal faults (Figs 1 and 2). The Vallès-Penedès fault dips $70^{\circ}$ to the SE near the ground surface and has a vertical displacement of $4 \mathrm{~km}$, whereas the Barcelona fault dips $35^{\circ}$ to the SE near the ground surface and has a vertical displacement of $8.5 \mathrm{~km}$ (Bartrina et al. 1992).
The structure and sedimentology of the sediments filling the Vallès-Penedès half-graben (Fig. 3) and the offshore Catalan margin (Agustí et al. 1985; Bartrina et al. 1992; Cabrera \& Calvet 1996; Roca et al. 1999) allow us to define four major stages in the tectonic evolution of the Catalan Coastal Ranges from the late Oligocene to the present:

i. A syn-rift stage lasting from the end of the Oligocene until the end of the lower Miocene, with strong extensional activity that gave rise to the present horst-andgraben structure.

ii. A post-rift stage lasting from the middle Miocene (Langhian) to upper Miocene (Tortonian), during which extensional tectonics were attenuated and only the Vallès-Penedès and Barcelona major faults were active. During the late Langhian to early Serravallian portion of this stage, a minor compressive event with a main regional stress $\left(\sigma_{1}\right)$ oriented NNE-SSW reactivated some pre-existing faults as strike-slip or reverse faults (Bartrina et al. 1992; Parcerisa et al. 2007).

iii. An upper Miocene (Messinian) contractional event that inverted the Vallès-Penedès fault with a minimum finite stretch direction more or less perpendicular to the main faults. This inversion uplifted and folded the basin fill deposits in a gentle syncline. The constant thickness of the folded basin fill deposits indicates that this syncline is not related to the extensional motion of the Vallès-Penedès fault, but to the structure generated during the Messinian.

iv. A final stage of relative tectonic inactivity in which flatlying Pliocene to Recent strata that unconformably overlie the basin-fill deposits record both the end of syncline development and a lack of significant activity in the main faults affecting the Vallès-Penedès halfgraben.

The Vallès-Penedès half-graben consists of two major sub-basins: the Vallès sub-basin and the Penedès sub-basin, separated by a transfer zone oriented NW-SE in which hectometre scale NNE-SSW and NW-SE-oriented normal faults developed. This transfer zone connects two parallel segments of the Vallès-Penedès fault with a right lateral offset of $5 \mathrm{~km}$, where the Llobregat River is incised (Fig. 1B).

The Vallès-Penedès half-graben, which is up to $100 \mathrm{~km}$ long and $10-14 \mathrm{~km}$ wide, is filled with up to $4 \mathrm{~km}$ thick successions of terrigenous sediments which have been divided into three depositional complexes (Cabrera et al. 1991; Cabrera \& Calvet 1996): (1) a lower continental complex, of Aquitanian-early Langhian age; (2) a continental to marine complex, of Langhian age, with reefal carbonate platforms; and (3) an upper continental complex of middle Serravallian-Tortonian age (Fig. 3). The fractures selected for this study are located at the southern edge of the transfer zone (Figs 1 and 2) in the lower continental 


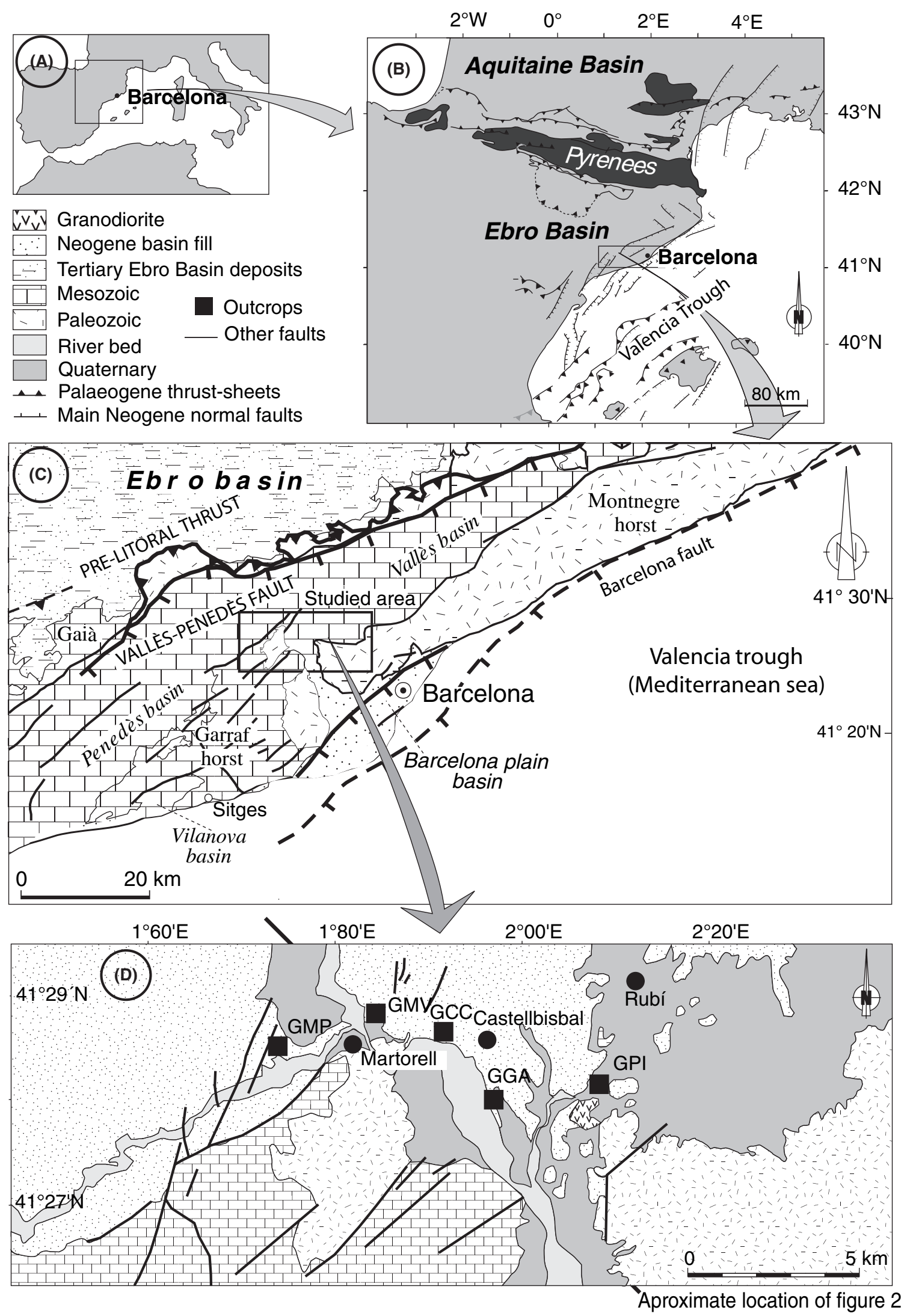

Fig. 1. Progressively enlarged maps of the Vallès-Penedès half-graben (A-C) and (D) location of the outcrops studied (GMP, GMV, GCC, GGA and GPI). 
complex, which consists of thick red bed sequences deposited in alluvial fan environments. They affect the upper part of the upper detrital unit, which is characterized by sediments derived from the northern margin (Parcerisa et al. 2005 ).

Three of the five studied outcrops (GCC, GMP and GMV) are located in the intermediate parts of the alluvial fans and consist of metre-scale layers of red lutites alternat- ing with decimetre to metre-scale sandstone layers and minor conglomerate lenses. The other two outcrops (GGA and GPI) are located on the distal parts of the alluvial fans and are mainly composed of red lutites with minor centimetre-scale sandstone beds (Fig. 2C).

Two successive sets of extensional structures have been distinguished (Fig. 4): the earlier set (set 1) consists of joints filled with shales, green sandstone and local
(A) NW

\section{EBRO}

Basin
Catalan coastal ranges
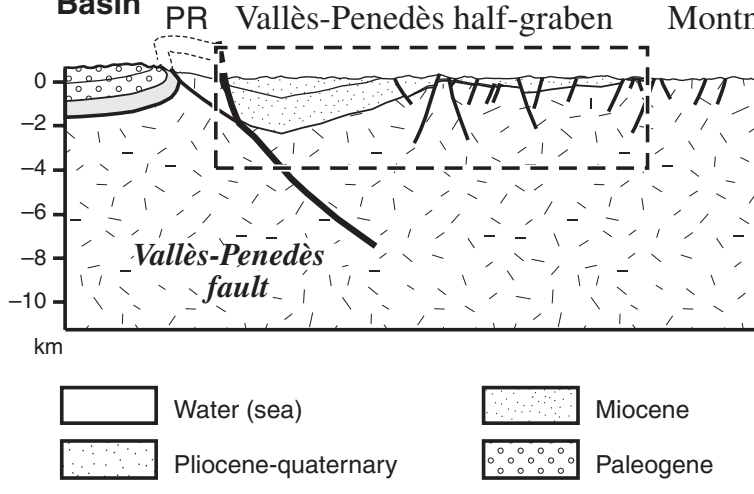

Water (sea)

Pliocene-quaternary

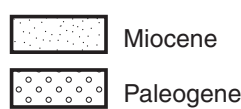

\section{SE}

\section{Valencia trough}

Barcelona half-graben

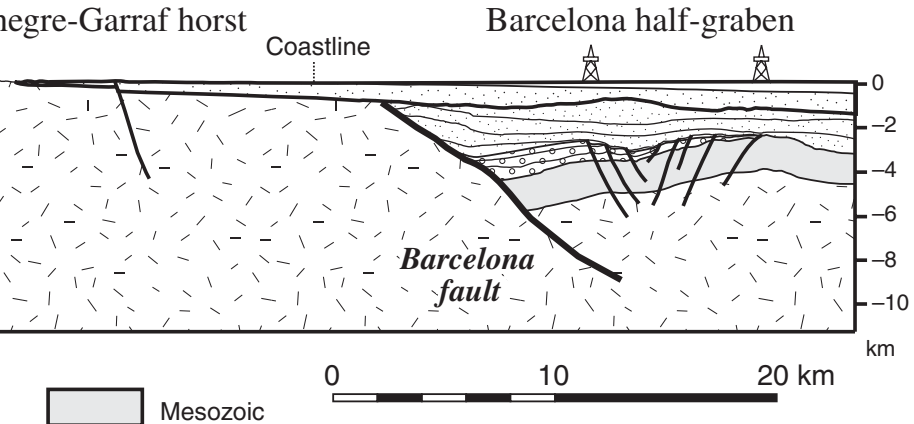

(B) NW

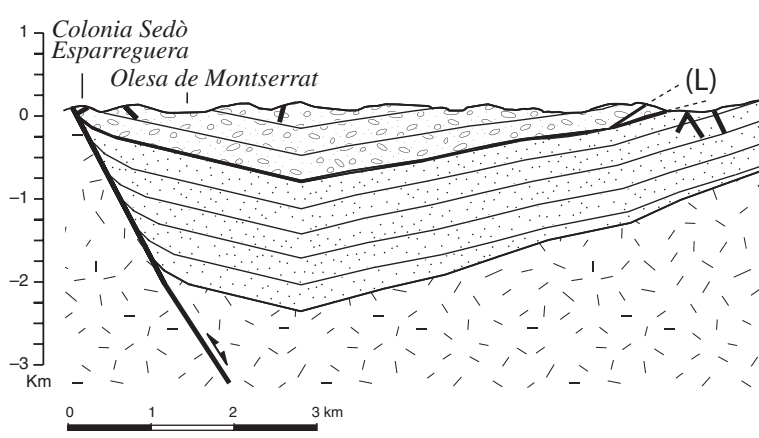

GMP<smiles>[CH]1[CH]C1</smiles>
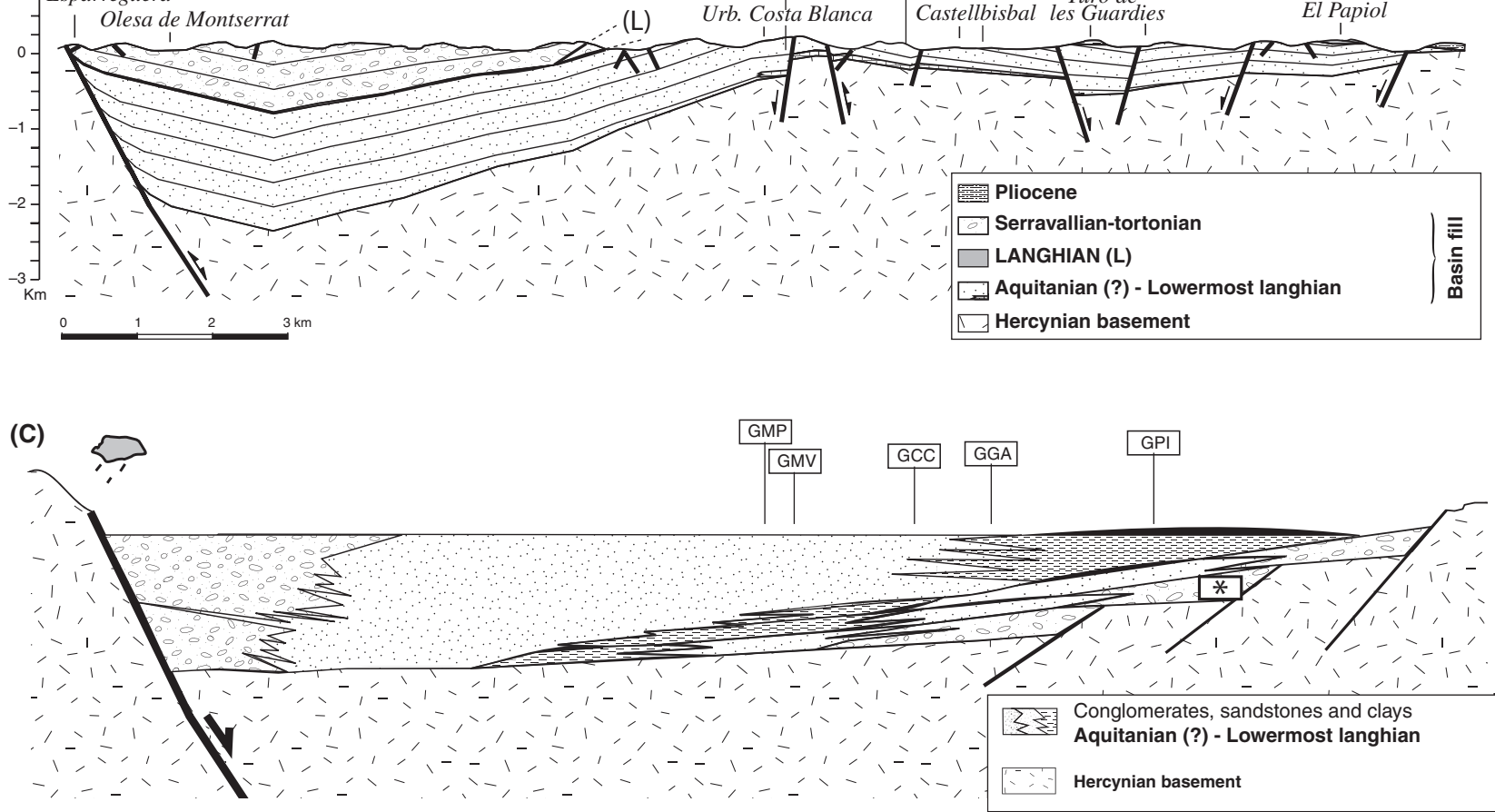

Fig. 2. (A) Schematic structural cross-section of the Catalan Coastal Ranges with the Vallès-Penedès half-graben. (B) Enlarged area of (A) showing a structural cross-section of the Vallès-Penedès half-graben with location of the studied outcrops. (C) Reconstruction of the depositional setting during the Upper Burdigalian, with location of the studied outcrops. The $\left(^{*}\right)$ indicates the location of previously studied outcrops of conglomerates of the Lower Detrital Unit that correspond to the proximal parts of the alluvial fans prograding from the southern margin. 


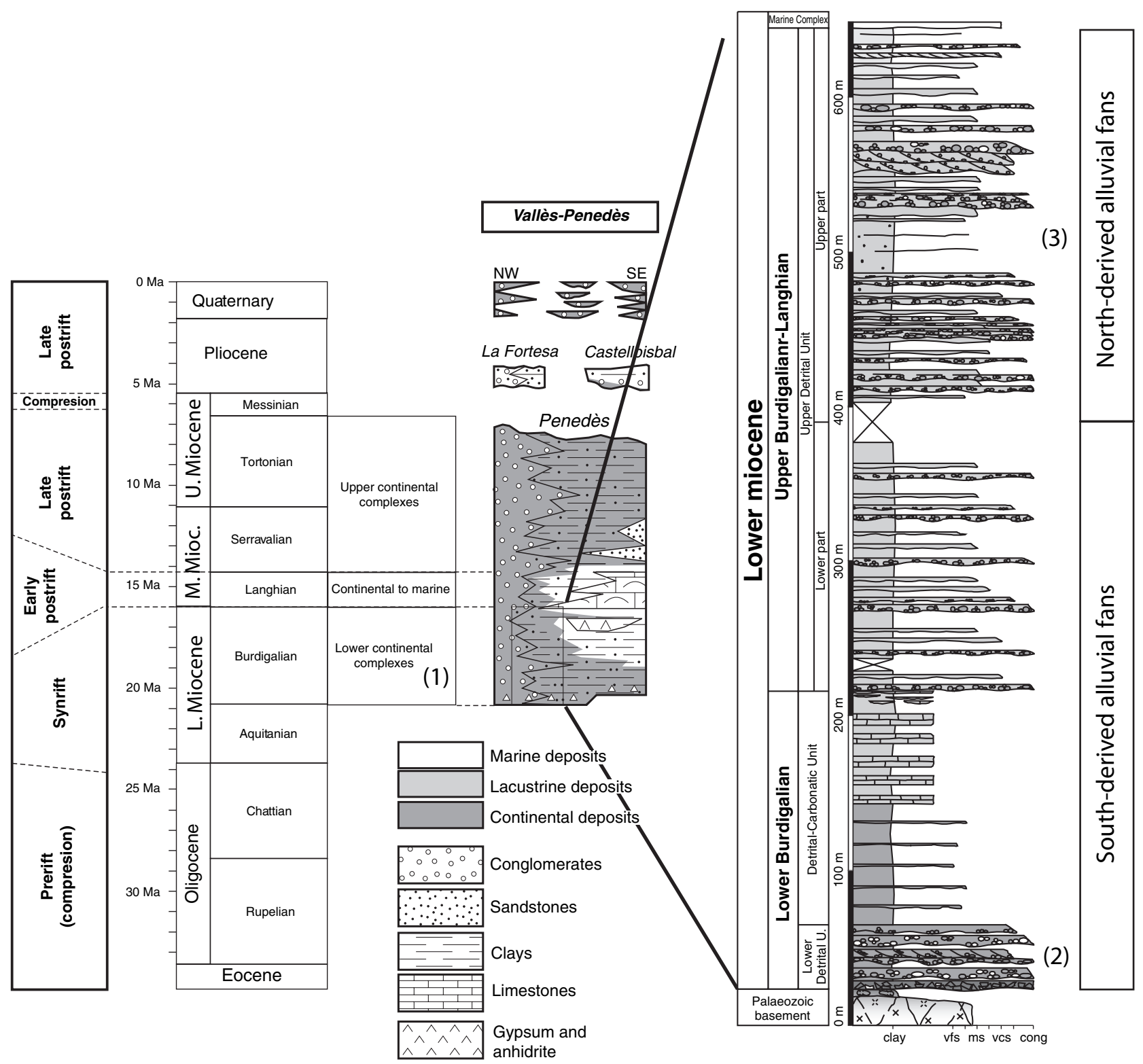

Fig. 3. Local stratigraphy of the Miocene lower continental complex. (1) Location of the fractures studied by Parcerisa et al. (2005, 2006), (2) location of the fractures studied by Travé \& Calvet (2001), (3) location of the fractures investigated in the study.

conglomerate that reach $20 \mathrm{~cm}$ in width and extend many metres vertically. These joints preferentially strike NE-SW and NW-SE, although E-W strike directions are also present (Fig. 5). The second set (set 2) is made up of normal faults and dilating extensional shear fractures (GMP outcrop) that are predominantly oriented NE-SW, NW-SE and N-S (Fig. 5), with vertical displacements ranging from a few centimetres to $4 \mathrm{~m}$, and are filled with calcite and lesser amounts of barite cements. The scattered orientations of the joints and faults, many of which are not parallel to the major faults bounding the basin, are due to their location in the transfer zone between the Vallès and the Penedès sub-basins.
The joints filled with clastic sediments (set 1) are interpreted to be clastic dikes that formed very soon after sedimentation due to seismically induced liquefaction (Obermeier 1996; Parcerisa 2002; Niemi et al. 2004; Jonk et al. 2005; Levi et al.2006). Extensional faults (set 2) filled with calcite cements cross-cut the earlier joints. Both sets of structures are affected by the tilting resulting from Messinian compressive deformation. Therefore, they are synchronous with the extensional tectonic regime that created this half-graben.

Although there are no studies that establish maximal $P-T$ conditions attained by sediments in the region, our own structural reconstruction of the basin indicates that 


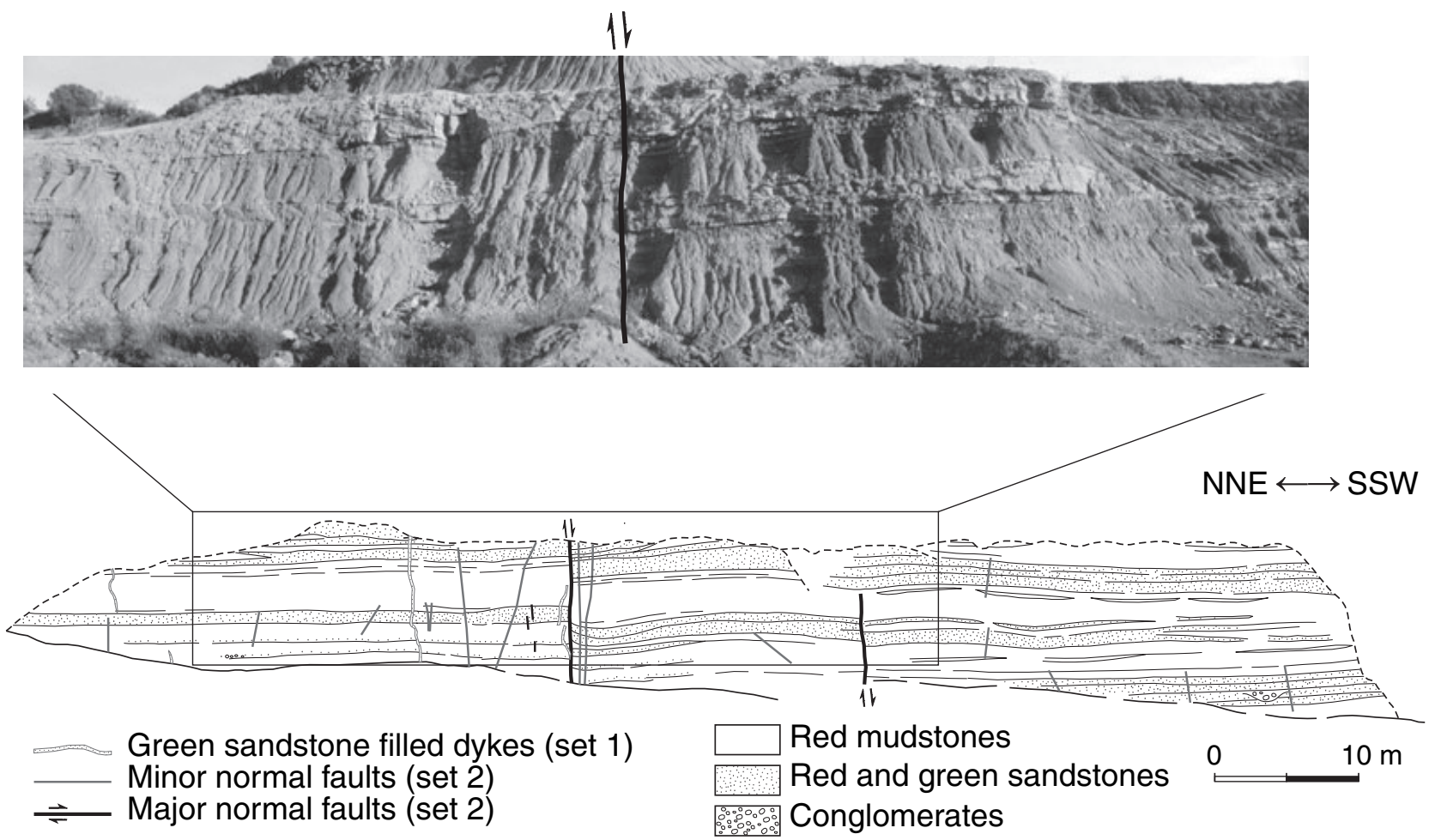

Fig. 4. General cross-section and field details of GMP outcrop, showing the two sets of extensional structures.

during Langhian times the sediments in the GMP outcrop were buried to less than $100 \mathrm{~m}$, and the other outcrops to only a few hundred metres. From Langhian times to present, all the outcrops have probably been buried between 500 and $1000 \mathrm{~m}$.

\section{METHODS AND ANALYTICAL TECHNIQUES}

Petrographic and geochemical study of the calcite cements filling the normal faults applied the following procedure. Standard and polished thin sections of approximately 100 samples from the five outcrops were examined using a petrographic microscope and a Technosyn Cold Cathodoluminescence Model 8200 MkII microscope operating at 16-19 kV and a gun current of $350 \mu \mathrm{A}$.

A total of $11 \mathrm{C}$-metallized polished thin sections were analysed using a CAMECA model SX-50 microprobe equipped with four vertically displayed WD X-ray spectrometers. The microprobe was operated using $20 \mathrm{kV}$ of excitation potential, $15 \mathrm{nA}$ of current intensity and $10 \mu \mathrm{m}$ of beam diameter. The detection limits were 180 p.p.m. for $\mathrm{Mn}, 275$ p.p.m. for $\mathrm{Fe}, 195$ p.p.m. for Na, 395 p.p.m. for $\mathrm{Mg}$ and 275 p.p.m. for Sr. Precision on major element analyses averaged $6.32 \%$ standard error at 3 sigma confidence levels.

For carbon and oxygen stable isotope analyses, $\mathrm{CO}_{2}$ was extracted from $10 \mathrm{mg}$ of 23 powdered carbonate samples which reacted with $103 \%$ phosphoric acid for $60 \mathrm{~min}$ under vacuum at $25^{\circ} \mathrm{C}$. The $\mathrm{CO}_{2}$ was analysed using a Finnigan MAT delta $S$ mass spectrometer. The results were corrected using standard procedures (Craig \& Gordon $1965)$ and are expressed in \% notation with respect to the PDB standard. The precision is $\pm 0.02 \%$ for $\delta^{13} \mathrm{C}$ and ${ }_{ \pm} 0.12 \%$ for $\delta^{18} \mathrm{O}$.

For $\delta^{34} \mathrm{~S}$, the $\mathrm{SO}_{2}$ was extracted from two barite cements following the standard procedure for sulphates (Coleman \& Moore 1978; modified from Robinson \& Kusakabe 1975). The $\mathrm{SO}_{2}$ was analysed using a SIRA Series II VG Isotech mass spectrometer. The values, which are expressed in \% notation relative to the CDT standard, have a precision of $\pm 0.1 \%$.

For the ${ }^{87} \mathrm{Sr} /{ }^{86} \mathrm{Sr}$ analyses, six powdered microsamples of $100 \%$ calcite (average $10^{-5} \mathrm{~g}$ ) from the veins were fully dissolved in $\mathrm{HCl}$ and analysed on a VG Sector 54 mass spectrometer. During the analysis of these samples the mean ${ }^{87} \mathrm{Sr} /{ }^{86} \mathrm{Sr}$ value of the measured NBS-987 standard was $0.710258 \pm 2$, which is within the error range of the accepted value of $0.710260 \pm 0.00002(2 \sigma, n=179)$.

\section{CALCITE VEINS FILLING THE FRACTURES}

\section{Petrology}

The normal faults are filled with shear veins that are commonly $1 \mathrm{~mm}$ to $2 \mathrm{~cm}$ thick and metres to decametres in lateral extent. The veins are bounded by striated shear 


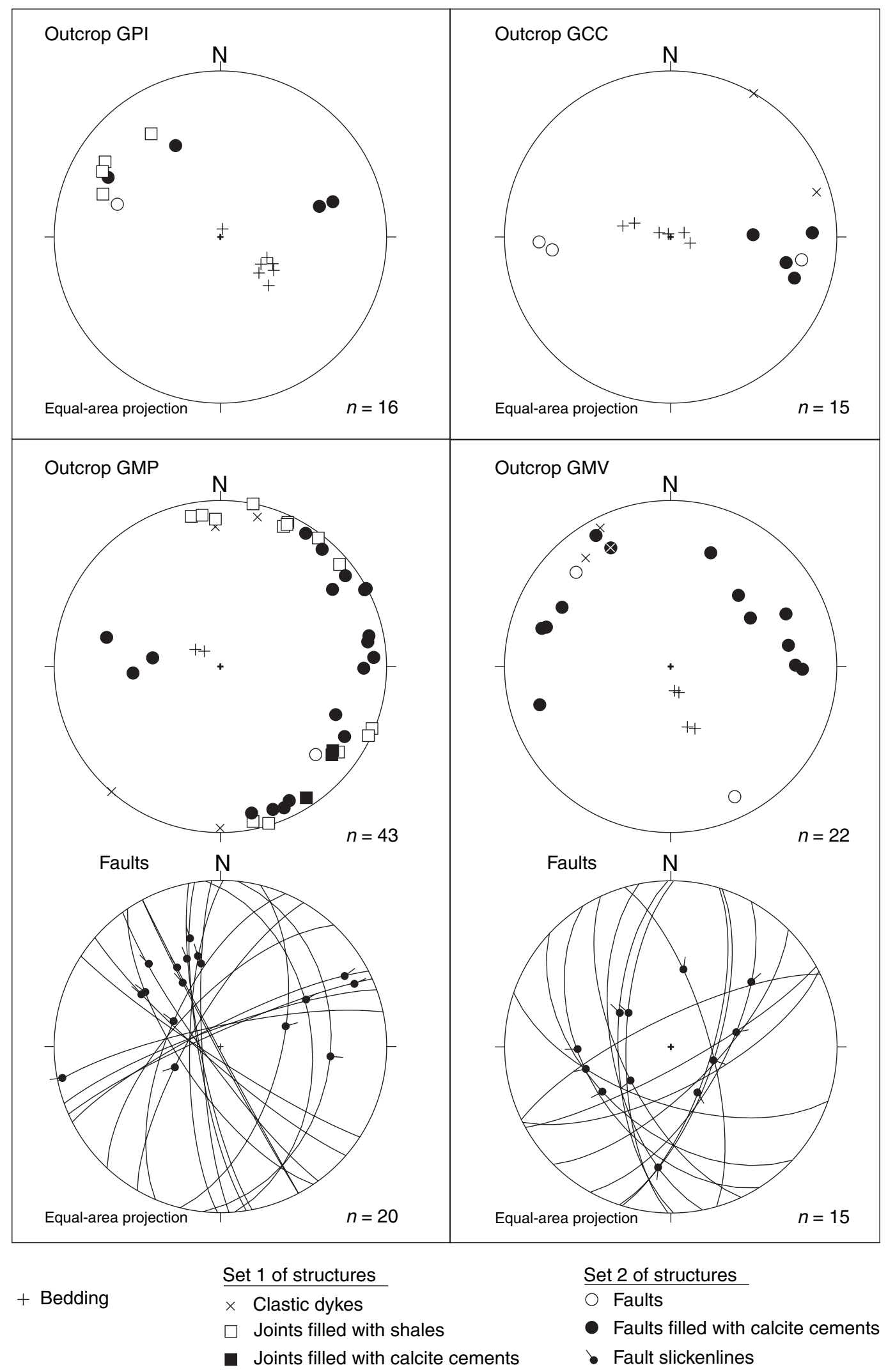

Fig. 5. Plots showing the poles of planes of structural features (joints and faults) in Schmidt lower hemisphere projection. 


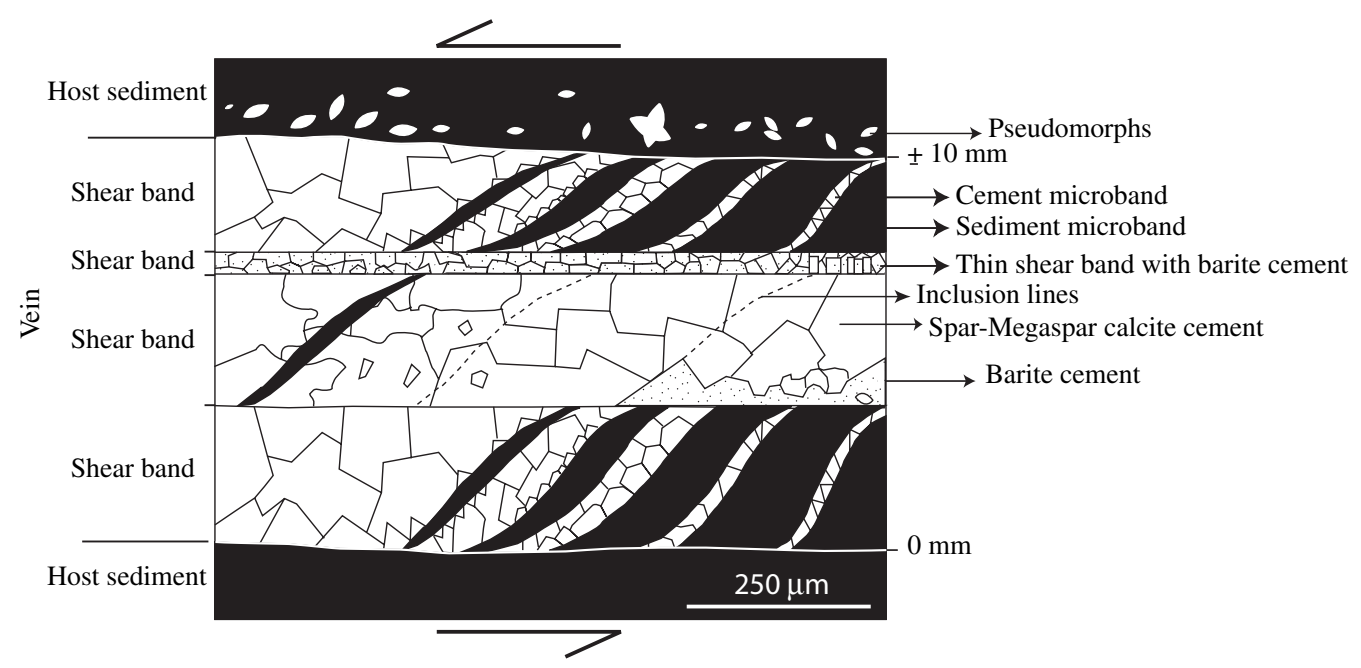

Fig. 6. Main petrographic characteristics of the shear veins.

surfaces and contain up to 10 (normally three or four) shear bands, which taper laterally into the host sediment (Figs 6 and 7A).

The shear bands, from 0.3 to $8 \mathrm{~mm}$ thick, consist of sediment microbands and cement microbands displaying an oblique disposition, sometimes with a sigmoidal morphology relative to the shear band boundaries (Fig. 7B). The microbands correspond to successive openings between shear surfaces that led to incremental vein development by a crack-seal mechanism (Ramsay 1980); the obliquity of the microbands with respect to the shear surfaces indicates the sense of shear (Labaume et al. 1991).

The sediment microbands, which have a dull orange cathodoluminescence, are made up of clays, microspar calcite crystals from 7 to $21 \mu \mathrm{m}$, and silt-size quartz grains (Fig. 7C). The cement microbands (Fig. 7C) are filled by calcite and (locally) barite cement (Fig. 7D). The calcite cement consists of euhedral-subeuhedral-anhedral spar calcite crystals at least $21 \mu \mathrm{m}$ in length, with equant to elongate morphology, increasing in size with increasing thickness of the calcite microband. The thicker calcite microbands are filled by complex crystals up to $1 \mathrm{~cm}$ in size that exhibit deformation structures such as mechanical twinning planes and undulating extinction, and include small crystals that impart a poikilitic texture. Intercrystalline boundaries can be straight, curved or lobate. The $c$-axis of the elongated complex crystals are parallel to the shear band boundaries and show inclusion lines from few a micrometres to $21 \mu \mathrm{m}$ in thickness, which are interpreted to be very thin sediment microbands that allowed the growth of large crystals over several successive openings. These spar calcite crystals have bright orange cathodoluminescence (Fig. 7E).

The barite cement, present only in the GMP and GMV outcrops, consists of euhedral to anhedral non-luminescent crystals (Fig. 7D,E) that range from $14 \mu \mathrm{m}$ to $1 \mathrm{~mm}$ in length and can appear either as individual crystals or as aggregates. The barite cement is located close to the shear band boundaries or entirely fills the thinner shear bands. The barite crystals are locally replaced by anhedral-subhedral miscrospar-spar calcite crystals.

The host sediment adjacent to the shear veins (Fig. 6) displays two distinct diagenetic textures: millimetre-thick zones consisting of abundant lenticular calcite crystals from $50 \mu \mathrm{m}$ to $1 \mathrm{~mm}$ in length that are interpreted to be gypsum pseudomorphs, and layers of calcite from $100 \mu \mathrm{m}$ to $2 \mathrm{~mm}$ thick, made up of bright-yellow luminescent prismatic calcite, with the $c$-axes perpendicular to the layer surface that form a complex network (Fig. 7F).

\section{Elemental geochemistry}

The $\mathrm{Mg}, \mathrm{Fe}$ and $\mathrm{Sr}$ content of the vein calcite cements varies significantly within each outcrop. $\mathrm{Mg}$ content ranges from 450 to 5700 p.p.m., Fe content ranges from below the detection limit to 7100 p.p.m. and Sr content ranges from below the detection limit to 3000 p.p.m. (Table 1). The biggest difference between the outcrops is the Mn content. In the GCC, GMP and GMV outcrops, located in the intermediate parts of the alluvial fans, Mn content ranges from 1920 to 17689 p.p.m. (average 7675 p.p.m.), whereas in the GGA and GPI outcrops, located in more distal parts of the alluvial fans, Mn content ranges from 11576 to 29325 p.p.m. (average 18055 p.p.m.). Within each outcrop, calcite cements show a good positive covariation between $\mathrm{Mn}$ and $\mathrm{Mg}$ content, with $r$ varying from 0.66 to 0.91 (Fig. 8). The barite cements contain between $56.9 \%$ and $58.9 \%$ $\mathrm{Ba}$, between $12.5 \%$ and $13.7 \%$ S, between 2200 p.p.m. and 10445 p.p.m. Sr, between the detection limit and 700 p.p.m. of $\mathrm{Na}$, and $\mathrm{Ca}$ and $\mathrm{Fe}$ mostly below the detection limit (Table 2). 


\section{Stable isotopes}

Calcite cements in the veins show $\delta^{18} \mathrm{O}$ values ranging from $-16.8 \%$ to $-11.7 \%$ PDB and $\delta^{13} \mathrm{C}$ values ranging from $-7.2 \%$ to $-6.1 \%$ PDB, all the values showing a good positive covariation with $r=0.83$ (Table 3, Fig. 9). The most depleted values correspond to the GPI outcrop and the most positive to the GMV outcrop. The two barite cements display $\delta^{34} S$ values of $+14.2 \%$ and $+15.7 \%$ CDT (Table 3 ).

\section{${ }^{87} \mathrm{Sr} /{ }^{86} \mathrm{Sr}$}

The ${ }^{87} \mathrm{Sr} /{ }^{86} \mathrm{Sr}$ ratios of calcite cements from fractures in the GMP and GMV outcrops range from 0.71081 to 0.71208 (Table 4) and are positively correlated with $\delta^{18} \mathrm{O}$ values $(r=0.94)$ (Fig. 10). The only ${ }^{87} \mathrm{Sr} /{ }^{86} \mathrm{Sr}$ value measured in calcite cement from the more distal outcrops is 0.71076 (Table 4 ) and does not fit the correlation line of ${ }^{87} \mathrm{Sr} /{ }^{86} \mathrm{Sr}$ $\delta^{18} \mathrm{O}$ values defined by the other samples.

\section{DISCUSSION}

\section{Relationship between fluids and deformation}

The fractures examined in this study occur in Burdigalian sediments deposited during the syn-rift stage, and are affected by the tilting resulting from Messinian compression. Therefore, formation of the faults and their calcite cements took place between the Burdigalian and the Messinian.

Incremental development of the veins, with alternation of sediment microbands and cement microbands, is interpreted to have occurred through an episodic crack-seal process. This mechanism implies cyclic cementation, rupturing and drainage. The very great number of successive ruptures, with preservation of delicate sediment microbands from one microband to another, suggests slow propagation of cracks. Thus, cements in the faults most likely formed through a crack-seal mechanism during interseismic episodes (Boullier \& Robert 1992; Robert et al. 1995; Lee \& Wiltschko 2000). Each microband can tentatively be correlated with a dilational fault jog. Fluid pressure increases progressively and, when dilation produces a rupture increment at a specific structural site (i.e. dilational jog, microband), a very small stress release (Renard et al. 2005) with a localized transient reduction in fluid pressure takes place. Precipitation of cement in a single microband reflects individual stress release episodes, and successive microbands can be related to successive stress cycles and linked to permeability. The crack-seal mechanism indicates that the fractures were filled by the cement synchronously with their development.

In an extensional tectonic regime, vertical extensional fractures may develop at shallow depth $(<1-2 \mathrm{~km})$ at hydrostatic fluid pressures (Secor 1965). Veins with textures similar to those described in the present work have previously been described in the Gulf of Mexico (Lee \& Wiltschko 2000). There, the veins are found at similarly shallow burial depths (between 1 and $2.7 \mathrm{~km}$ ) in structures related to extension of the Gulf. Faults and fractures from the present study are hosted in sedimentary strata that have been buried $<1 \mathrm{~km}$, and were probably formed at the tips of larger normal faults that controlled the basin. They could be related to adjustment around large normal faults developed during the seismic rupture (Sibson 2000; Labaume et al. 2004). The structures in this study could correspond to a high-permeability horsetail extensional fault-fracture mesh developed near the ground surface in the hanging walls of normal faults (Sibson 2000) under nearly hydrostatic fluid pressure conditions.

\section{Stable isotopes}

Differences in $\delta^{18} \mathrm{O}$ values of the calcite cements (from $-16.8 \%$ to $-11.7 \%$ PDB) may reflect differences in precipitation temperature or water composition. Present-day meteoric water in north-east Spain has $\delta^{18} \mathrm{O}$ values ranging from $-8 \%$ to $-6.3 \%$ SMOW (Plata 1994; Redondo \& Yélamos 2000). As the palaeolatitude of the Penedès basin during the Miocene was only $4^{\circ}$ south of its present-day latitude (Smith 1996), $\delta^{18} \mathrm{O}$ values of the meteoric water during the Miocene were most probably within the same range as present-day waters. If the calcite cements precipitated from unmodified meteoric waters, their oxygen isotope compositions would correspond to temperatures of $34-75^{\circ} \mathrm{C}$, based on the equation of Craig (1965), $T=16.9-4.2\left(\delta^{18} \mathrm{O}_{\text {calcite }}-\delta^{18} \mathrm{O}_{\text {water }}\right)+0.13\left(\delta^{18} \mathrm{O}_{\text {calcite }}-\right.$ $\left.\delta^{18} \mathrm{O}_{\text {water }}\right)^{2}$. Based on their occurrence in continental sediments that likely were never buried more than $1 \mathrm{~km}$, a modern-day geothermal gradient of $1-3^{\circ} \mathrm{C} / 100 \mathrm{~m}$ (Fernàndez \& Banda 1988) and an assumed surface temperature of $25^{\circ} \mathrm{C}$, the maximum calcite precipitation temperature was $<55^{\circ} \mathrm{C}$. Thus, burial temperatures at the current geothermal gradient would not have been sufficiently high to account for the relatively low $\delta^{18} \mathrm{O}$ values of the calcite cements. However, because these fractures developed synchronously with rifting, the geothermal gradient may have been higher due to lithospheric thinning (McKenzie 1978), helping to explain the low $\delta^{18} \mathrm{O}$ values at such shallow burial depths. The $\delta^{13} \mathrm{C}$ values, ranging between $-7.2 \%$ and $-6.1 \%$ in shallow environments, may reflect the influence of organic carbon (Cerling 1984). The narrow range of $\delta^{13} \mathrm{C}$ values may result from precipitation of the calcite cements within a relatively narrow depth range that taps only a small part of the carbon isotope reservoir (Tasse \& Hesse 1984), or may indicate that the $\delta^{13} \mathrm{C}$ value of the carbon reservoir did not change much with depth. Low $\delta^{34} S$ values of the 

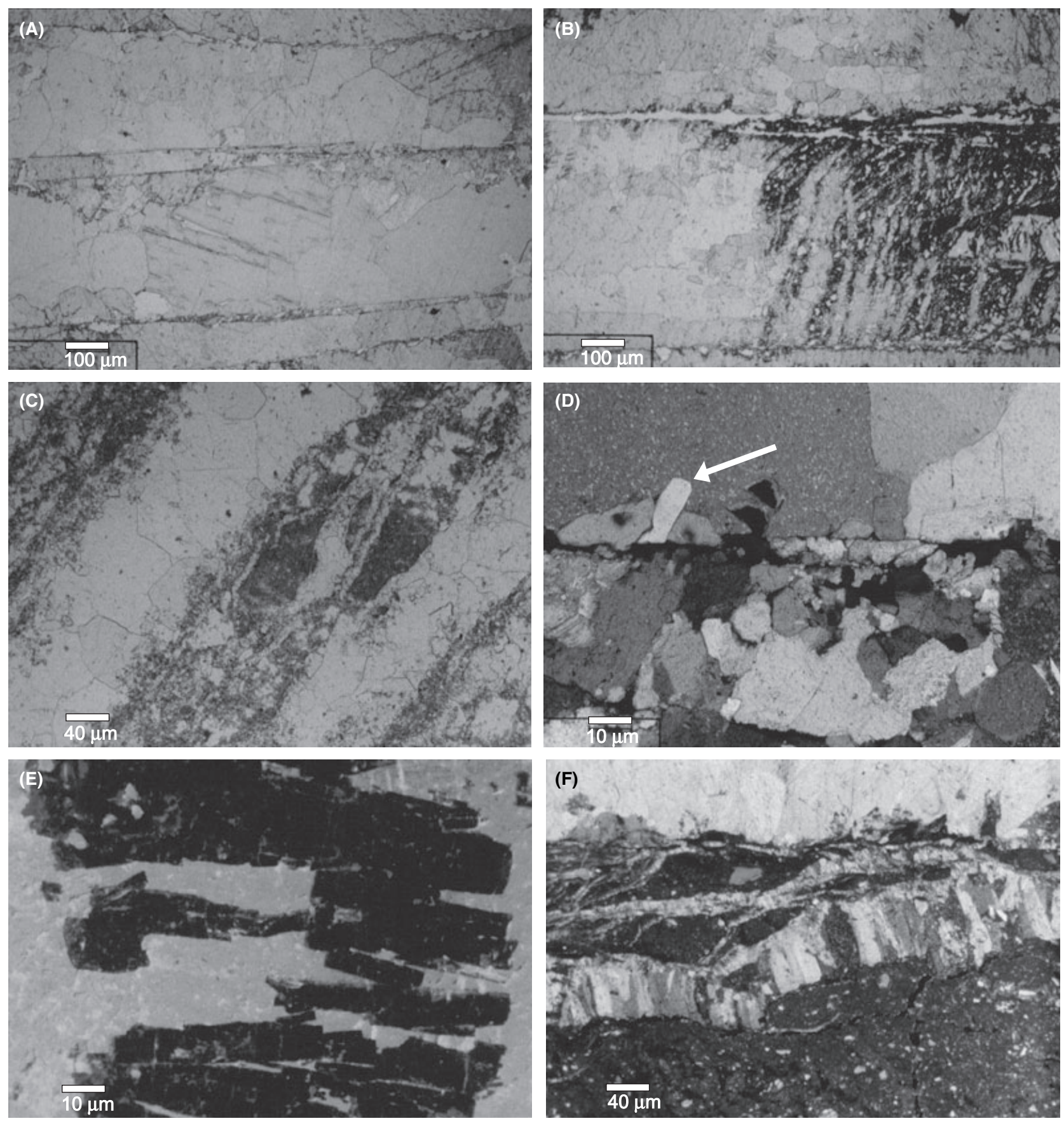

Fig. 7. (A) Microphotograph of shear bands filled by spar calcite cement. (B) Microphotograph of a shear band filled by spar calcite cement (top and bottom left) and sediment microbands (darker areas) alternating with cement microbands (bottom right). These microbands correspond to a crack-seal structure. (C) Detail of the alternation of sediment microbands (darker areas) and cement microbands (clearer areas) in the shear bands forming the veins. (D) Detail of the two shear bands filled by spar calcite cement with barite cement (arrow) located close to the shear band boundary. (E) Elongated non-luminescent barite cement and bright-orange luminescent calcite cement. (F) Layer of prismatic calcite within the host sediment near the shear vein.

barite cements, ranging from $+14.2 \%$ to $+15.7 \%$ o $\mathrm{CDT}$, indicate that the source of the $\mathrm{S}$ was mainly dissolution of marine Triassic evaporites, which have $\delta^{34} S$ values ranging from $+9 \%$ to $+15 \%$ CDT (Utrilla et al. 1991, 1992) and are present on both margins of the basin.

\section{${ }^{87} \mathrm{Sr} /{ }^{86} \mathrm{Sr}$ values}

The ${ }^{87} \mathrm{Sr} /{ }^{86} \mathrm{Sr}$ ratios of the calcite cements $(0.71076-$ 0.71208 ) are near the average global river flux value of 0.711 (Veizer 1992). The calcite cements may have acquired their high strontium isotope ratios by 
Table $1 \mathrm{Ca}, \mathrm{Mg}, \mathrm{Mn}, \mathrm{Fe}$ and $\mathrm{Sr}$ content of calcite cements in shear vein fracture fillings.

\begin{tabular}{|c|c|c|c|c|c|}
\hline & $\mathrm{Ca}$ & $M g$ & $\mathrm{Mn}$ & $\mathrm{Fe}$ & $\mathrm{Sr}$ \\
\hline \multicolumn{6}{|l|}{$\operatorname{GCC}(n=17)$} \\
\hline Minimum & 371111 & 882 & 3087 & $<$ d.I. & $<$ d.I. \\
\hline Maximum & 392491 & 2021 & 10926 & 1205 & 777 \\
\hline Mean & 382001 & 1533 & 8211 & 232 & 394 \\
\hline SD & 7228 & 377 & 1875 & 305 & 201 \\
\hline \multicolumn{6}{|c|}{$\mathrm{GMP}(n=115)$} \\
\hline Minimum & 377342 & 450 & 2242 & $<$ d.l. & $<$ d.I. \\
\hline Maximum & 414627 & 3570 & 10386 & 1446 & 1680 \\
\hline Mean & 388815 & 2158 & 5965 & 196 & 510 \\
\hline SD & 5734 & 771 & 1776 & 236 & 344 \\
\hline \multicolumn{6}{|c|}{ GMV $(n=125)$} \\
\hline Minimum & 371839 & 456 & 1921 & $<$ d.l. & $<$ d.I. \\
\hline Maximum & 395514 & 3578 & 17689 & 1629 & 1353 \\
\hline Mean & 381510 & 1928 & 9181 & 175 & 491 \\
\hline SD & 4719 & 714 & 2452 & 258 & 302 \\
\hline \multicolumn{6}{|l|}{ GGA $(n=22)$} \\
\hline Minimum & 348254 & 461 & 11576 & $<$ d.l. & $<$ d.I. \\
\hline Maximum & 379260 & 2457 & 26043 & 1870 & 588 \\
\hline Mean & 365021 & 1768 & 20015 & 549 & 197 \\
\hline SD & 7770 & 551 & 4222 & 623 & 219 \\
\hline \multicolumn{6}{|l|}{$\mathrm{GPI}(n=48)$} \\
\hline Minimum & 361813 & 865 & 10323 & $<$ d.l. & $<$ d.I. \\
\hline Maximum & 399054 & 5703 & 29326 & 7106 & 3003 \\
\hline Mean & 379998 & 2696 & 17157 & 253 & 776 \\
\hline SD & 9052 & 1287 & 4623 & 1026 & 458 \\
\hline
\end{tabular}

$<$ d.I., below the detection limit of the microprobe.

incorporating radiogenic $\mathrm{Sr}$ derived from older Rb-rich source rocks such as the Paleozoic metamorphic rocks on the northern margin of the basin (Schultz et al. 1989; Morad et al. 1998). Rocks from the southern margin of the basin, which consist mainly of Mesozoic marine carbonates with ${ }^{87} \mathrm{Sr} /{ }^{86} \mathrm{Sr}$ ratios ranging from 0.70740 to 0.70743 (Travé et al. 1998), do not appear to have contributed sig- nificantly to the strontium isotope composition of the calcite cements, arguing against groundwater flow from the south.

\section{$\mathrm{Mn} / \mathrm{Ca}$ molar ratio in the fluid}

Assuming equilibrium precipitation of calcite, and knowing the distribution coefficient of $\mathrm{Mn}\left(D_{\mathrm{Mn}}\right)$, the $\mathrm{Mn} / \mathrm{Ca}$ molar ratio in the precipitating fluid can be calculated. $D_{\mathrm{Mn}}$ is not significantly affected by temperature variations when temperature is lower than $100^{\circ} \mathrm{C}$ (Bodine et al. 1965 ) but it is influenced by precipitation rate (Pingitore 1978; Lorens 1981; Mucci 1988; Dromgoole \& Walter 1990) varying from 5 at rapid precipitation rates to almost 70 at very low precipitation rates. Taking $D_{\mathrm{Mn}}=8$ and 15 , representing relatively rapid to intermediate precipitation rates, and applying the distribution coefficient equation of McIntire (1963), the values obtained for the Mn/Ca molar ratio in the fluid precipitating calcite cements vary between $1.28 \times 10^{-3}$ and $4.7 \times 10^{-4}$. These values are consistent with modified meteoric water, and not with seawater $\left(\mathrm{Mn} / \mathrm{Ca}\right.$ ratio around $3 \times 10^{-7}$ ) or formation water $\left(\mathrm{Mn} / \mathrm{Ca}\right.$ ratio around $\left.7 \times 10^{-5}\right)$ (Tucker \& Wright 1990). Prolonged interaction with Mn-bearing host sediment will have changed the original meteoric water composition. Only the cements with the lowest Mn contents, precipitating at the highest $D_{\mathrm{Mn}}$ value of 70 (assuming very low precipitation rates), could have formed from a fluid that approached the composition of formation water.

\section{Source of $\mathrm{Ba}^{2+}$}

$\mathrm{Ba}^{2+}$ for barite may have been derived from detrital feldspars during their alteration to clay, or from dissolution of

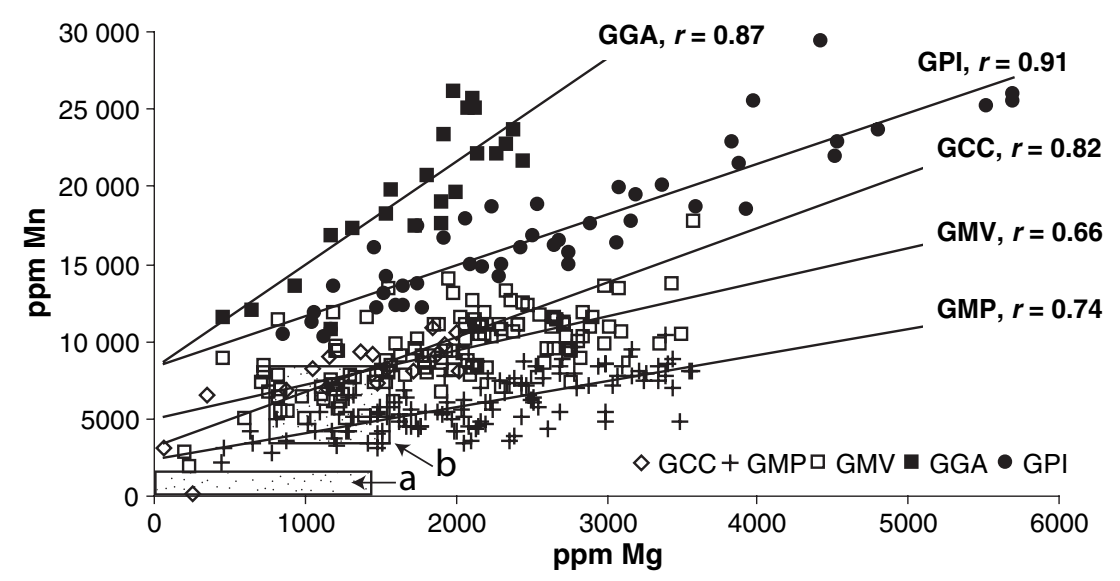

Fig. 8. Mn versus $\mathrm{Mg}$ content in vein calcite. The horizontal bar labelled (a) encompasses values for the calcite cements filling fractures in the Lower Detrital Unit as reported by Travé \& Calvet (2001) and for the sparry cement filling intergranular porosity in the Lower Detrital Unit as reported by Parcerisa et al. (2005). The rectangle labelled (b) encompasses values for the sparry cement filling intergranular porosity in the Upper Detrital Unit as reported by Parcerisa et al. (2005). 
Table $2 \mathrm{~S}, \mathrm{Ba}, \mathrm{Ca}, \mathrm{Fe}, \mathrm{Sr}$ and $\mathrm{Na}$ content of barite cements in shear vein fracture fillings.

\begin{tabular}{|c|c|c|c|c|c|c|}
\hline Sample & $\% \mathrm{~S}$ & $\% \mathrm{Ba}$ & p.p.m. Ca & p.p.m. Fe & p.p.m. Sr & p.p.m. Na \\
\hline GMP 11 & 13.2 & 57.1 & 29 & 109 & 2384 & 304 \\
\hline GMP 11 & 13.2 & 57.2 & 79 & 249 & 5691 & 619 \\
\hline GMP 11 & 13.3 & 57.0 & 29 & $<$ d.l. & 10443 & 553 \\
\hline GMP 11 & 13.5 & 57.4 & $<$ d.l. & 987 & 7416 & 408 \\
\hline GMP 11 & 13.3 & 57.2 & 21 & $<$ d.I. & 3560 & 579 \\
\hline GMP 11 & 13.3 & 57.4 & 64 & 552 & 4947 & 504 \\
\hline GMP 11 & 13.5 & 57.6 & 200 & $<$ d.I. & 3788 & 367 \\
\hline GMP 11 & 13.2 & 57.8 & 29 & $<$ d.I. & 4194 & 516 \\
\hline GMP 11 & 13.2 & 57.2 & $<$ d.I. & 132 & 5124 & 460 \\
\hline GMP 11 & 13.0 & 56.9 & $<$ d.I. & 31 & 5073 & 252 \\
\hline GMP 11 & 13.0 & 57.4 & $<$ d.I. & 148 & 3044 & 430 \\
\hline GMP 11 & 13.1 & 57.7 & 121 & 16 & 2689 & 274 \\
\hline GMP 11 & 12.9 & 58.0 & 57 & 342 & 2207 & 252 \\
\hline GMP 11 & 13.0 & 57.7 & $<$ d.I. & 31 & 3534 & 293 \\
\hline GMP 11 & 12.5 & 57.3 & 164 & 225 & 8515 & 527 \\
\hline GMP 11 & 12.6 & 56.9 & $<$ d.I. & 373 & 5217 & 263 \\
\hline GMP 11 & 12.8 & 57.5 & 7 & $<$ d.I. & 9741 & 568 \\
\hline GMP 11 & 13.0 & 57.6 & $<$ d.I. & $<$ d.I. & 8760 & 701 \\
\hline GMP 11 & 12.9 & 57.4 & 114 & $<$ d.I. & 7289 & 482 \\
\hline GMP 11 & 13.3 & 57.1 & 143 & 1174 & 8540 & 545 \\
\hline GMV 1 & 13.7 & 58.9 & 193 & 31 & 5352 & n.a. \\
\hline GMV 1 & 13.7 & 58.2 & $<$ d.I. & 140 & 5741 & n.a. \\
\hline GMV 1 & 13.4 & 58.3 & 322 & 365 & 5031 & n.a. \\
\hline GMV 1 & 13.6 & 58.2 & 29 & 280 & 6984 & n.a. \\
\hline GMV 1 & 13.3 & 58.7 & $<$ d.I. & 86 & 4667 & n.a. \\
\hline GMV 1 & 13.4 & 58.4 & $<$ d.I. & 117 & 5395 & n.a. \\
\hline GMV 1 & 13.1 & 58.8 & $<$ d.I. & 295 & 2689 & n.a. \\
\hline
\end{tabular}

n.a., not analysed.

Table $3 \delta^{18} \mathrm{O}$ and $\delta^{13} \mathrm{C}$ of the calcite and $\delta^{34} \mathrm{~S}$ of barite cements in shear vein fracture fillings.

\begin{tabular}{|c|c|c|c|c|}
\hline Lithology & Sample & $\delta^{18} \mathrm{O} \%$ PDB & $\delta^{13} \mathrm{C} \%$ PDB & $\delta^{34} \mathrm{~S} \%$ o CDT \\
\hline \multirow[t]{23}{*}{ Calcite } & GCC 1 & -13.5 & -6.4 & \\
\hline & GMP 2 & -13.4 & -6.4 & \\
\hline & GMP 3 & -13.2 & -6.5 & \\
\hline & GMP 4 & -13.8 & -6.6 & \\
\hline & GMP 6 & -12.9 & -6.5 & \\
\hline & GMP 8 & -14.2 & -6.7 & \\
\hline & GMP 11 & -12.8 & -6.6 & \\
\hline & GMP 12 & -14.3 & -6.7 & \\
\hline & GMP 16 & -14.5 & -6.7 & \\
\hline & GMP 18 & -14.4 & -6.7 & \\
\hline & GMP 19 & -14.3 & -6.8 & \\
\hline & GMP 20 & -14.9 & -6.9 & \\
\hline & GMP 23 & -13.6 & -6.4 & \\
\hline & GMV 1a & -11.7 & -6.1 & \\
\hline & GMV 5 & -12.8 & -6.5 & \\
\hline & GMV 6 & -13.2 & -6.3 & \\
\hline & GMV 8 & -14.1 & -7.1 & \\
\hline & GMV 11 & -14.1 & -7.0 & \\
\hline & GGA 1a & -13.5 & -6.7 & \\
\hline & GGA $1 b$ & -14.1 & -6.6 & \\
\hline & GPI 1 & -16.8 & -7.2 & \\
\hline & GPI 2 & -15.4 & -6.8 & \\
\hline & GPI 3 & -15.6 & -7.0 & \\
\hline \multirow[t]{2}{*}{ Barite } & GMV-1 & & & +14.2 \\
\hline & GMP-11 & & & +15.7 \\
\hline
\end{tabular}

Mn oxyhydroxides from the ferruginous matrix of the red beds. The association of $\mathrm{Ba}$ with $\mathrm{Mn}$-rich phases has been reported by many authors and a summary of this literature is provided by Neaman et al. (2004). In the present study area, the two outcrops with barite have calcite cements with the lowest Mn concentrations, pointing to the detrital feldspars as the most likely source.

\section{Source and precipitation of $\mathrm{Mn}^{2+}$}

High Mn contents in carbonates can be derived from (1) hydrothermal fluids (Russell 1975; Pomerol 1983; Tasse \& Hesse 1984; Gawthorpe 1987; Pfeifer et al. 1988; Pratt et al. 1991) or (2) bacterial reduction of manganese oxyhydroxides in organic-rich sediments undergoing diagenesis at shallow burial depths (Pedersen \& Price 1982; Mount \& Cohen 1984; Tasse \& Hesse 1984; Curtis et al. 1986; Emery 1987; Polgári et al. 1991; Pratt et al. 1991; Hendry 1993; Neaman et al. 2004). In the present study area, microbial metabolic processes progressively reduced the originally oxidizing meteoric water (Suess 1979; Mount \& Cohen 1984; Tasse \& Hesse 1984). These processes took place during shallow burial in a relatively confined aquifer. Through interaction with manganese oxyhydroxides, which are widespread in the ferruginous matrix of the host Burdigalian red bed deposits, the evolved meteoric fluid scavenged $\mathrm{Mn}$ in the divalent state. During subsequent lateral and/or ascending fluid-flow, it precipitated $\mathrm{Mn}$ as manganiferous calcite cement under favourable redox conditions, both within sandstones and as veins in faults/fractures within more distal mudstones.

Because $\mathrm{Mn}$ is dissolved in greater amounts at surface conditions than under deeper conditions (Hem 1964; Brockamp 1976), dissolution of $\mathrm{Mn}^{2+}$ probably took place soon after sedimentation, by meteoric water under moderate oxidizing conditions. As sufficient $\mathrm{Mn}$ was available from the red bed deposits, large amounts of organic matter were not needed to supply Mn (Brockamp 1976; Pedersen \& Price 1982; Tasse \& Hesse 1984). The high concentrations of $\mathrm{Mn}$ in meteoric water may be related to more humid climates (Brockamp 1976), which have been documented in the area during early Miocene time by Cabrera \& Calvet (1996).

Redox state of the fluid was likely the main parameter controlling precipitation of Mn-bearing carbonates (Barnaby \& Rimstidt 1989). Under oxidizing conditions, Mn is relatively insoluble, whereas under reducing conditions it is much more soluble, most commonly in the +2 oxidation state (Berner 1971). If both $\mathrm{Mn}$ and Fe-oxides are available to leach (as is the case in the Burdigalian sediments), leaching of $\mathrm{Mn}$-oxides only indicates intermediate redox potentials (Quinby-Hunt \& Wilde 1996).

The $\delta^{13} \mathrm{C}$ values of calcite cements in the fractures range from $-7.2 \%$ to $-6.1 \%$ PDB and are compatible with 
Fig. 9. $\delta^{18} \mathrm{O}$ versus $\delta^{13} \mathrm{C}$ cross plot for vein calcite.

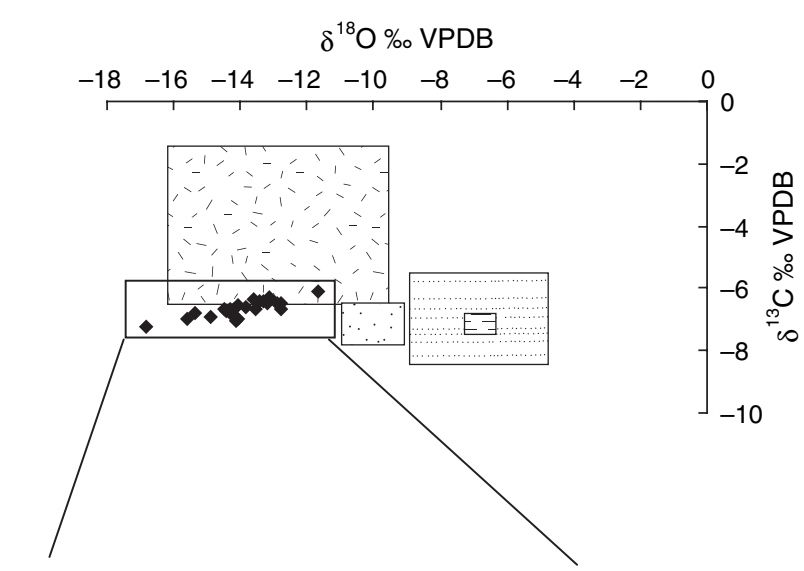

$\delta^{18} \mathrm{O} \%$ VPDB

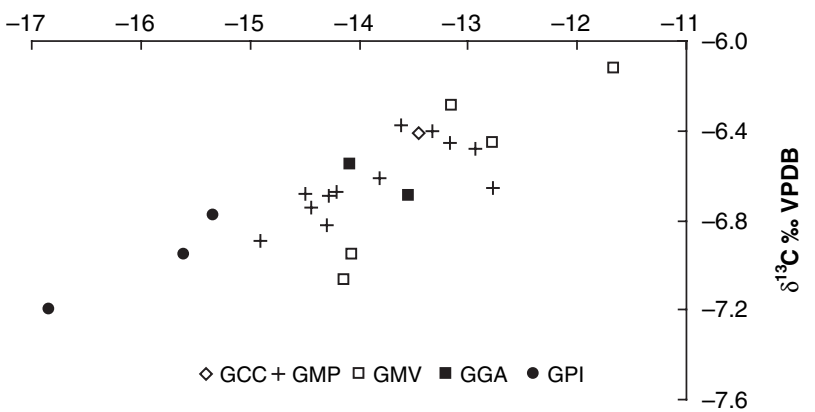

First fracture filling stage in proximal conglomerates of the LDU (Travé \& Calvet 2001) Second fracture filling stage in proximal conglomerates of the LDU (Travé \& Calvet 2001) Sparry cement filling intergranular porosity in the LDU (Parcerisa et al. 2005)

Sparry cement filling intergranular porosity in the UDU (Parcerisa et al. 2005)
Table $4{ }^{87} \mathrm{Sr} /{ }^{86} \mathrm{Sr}$ values of calcite cements in shear vein fracture fillings. The error noted is the instrumental one, estimated to be $0.01 \%$.

\begin{tabular}{lllllll}
\hline & & & {$[R b]$} & {$[S r]$} & & \\
Sample & Petrology & ${ }^{87} \mathrm{Sr} /{ }^{86} \mathrm{Sr}$ & p.p.m. & p.p.m. & ${ }^{87} \mathrm{Rb} /{ }^{86} \mathrm{Sr}$ & $\pm 2 \sigma$ \\
\hline GMP-2 & Spar & 0.71081 & 1.9 & 536 & 0.01008 & 18 \\
GMP-3 & Spar & 0.71086 & 0.6 & 616 & 0.00268 & 11 \\
GMP-6 & Spar & 0.71153 & 2.5 & 595 & 0.01235 & 26 \\
GMV-5 & Spar & 0.71208 & 1.9 & 443 & 0.01214 & 17 \\
GMV-6 & Spar & 0.71138 & 4.3 & 411 & 0.03042 & 23 \\
GPI-2 & Spar & 0.71076 & 6.2 & 500 & 0.03601 & 16 \\
\hline
\end{tabular}

precipitation from meteoric fluids in the upper end of the methanogenesis zone, where carbonates are isotopically heavier than in the overlying oxic and sulphate reduction zones (Presley \& Kaplan 1968) or in the underlying decarboxilation zone (Claypool \& Kaplan 1974; Curtis 1978; Pisciotto \& Mahoney 1981; Tasse \& Hesse 1984). In the methanogenesis zone, $\mathrm{Mn}^{2+}$ dissolved in negative Eh fluids may become available to enter into the carbonates (Tasse \& Hesse 1984).

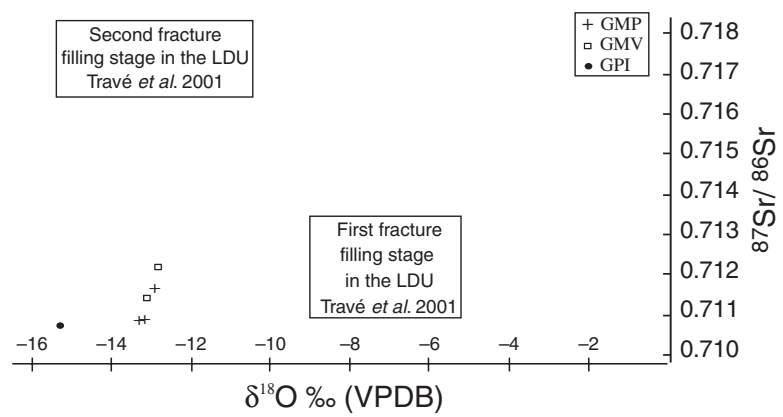

Fig. 10. $\delta^{18} \mathrm{O}$ versus ${ }^{87} \mathrm{Sr} /{ }^{86} \mathrm{Sr}$ cross plot for vein calcite.

\section{Fluid flow pattern in the Vallès-Penedès half-graben}

The aim of the present work was to provide new insights into fluid behaviour during early extension of the basin. The composition of the calcite cements filling fractures, both in the Mesozoic substrate surrounding the basin and in the Miocene deposits filling the Vallès-Penedès basin, indicates precipitation from formation waters. In addition, 
Table 5 Synthesis of the main lithological, structural and geochemical features in the studied outcrops. The arrows indicate minor or major proportion in the outcrops located in the intermediate parts of the alluvial fans (GCC, GMP and GMV) with respect to the outcrops located on the distal parts of the alluvial fans (GGA and GPI).

\begin{tabular}{|c|c|c|c|}
\hline Outcrops & Lithology & Fracture types & $\begin{array}{l}\text { Geochemical composition } \\
\text { of the calcite cement }\end{array}$ \\
\hline $\begin{array}{l}\text { GMP } \\
\text { GMV } \\
\text { GCC }\end{array}$ & $\begin{array}{l}\text { Red lutites, sandstones and minor } \\
\text { conglomerates }\end{array}$ & $\begin{array}{l}\text { Clastic dykes, normal faults } \\
\text { with calcite-barite cements } \\
\text { and joints filled with shales } \\
\text { or calcite }\end{array}$ & $\begin{array}{l}\downarrow M n \\
\uparrow \delta^{18} \mathrm{O}, \uparrow \delta^{13} \mathrm{C} \\
\uparrow^{87} \mathrm{Sr} /{ }^{86} \mathrm{Sr}\end{array}$ \\
\hline
\end{tabular}

it suggests high fluid-rock interaction and a relatively closed hydrological system during the Alpine Compression. During the subsequent Neogene extension, the hydrological system became more open, allowing the input of meteoric waters and lower levels of fluid-rock interaction (Travé et al. 1998). The calcite cements filling fractures within the lower Miocene (early Burdigalian) conglomerates along the margins of the basins indicate precipitation from meteoric waters and a change from a vadose environment to a phreatic meteoric environment (Travé \& Calvet 2001). Cementation of the basinal sediments that host the fractures occurred during early diagenesis at shallow burial depth by meteoric waters that changed in composition, particularly with respect to $\mathrm{Eh}$ and $\mathrm{pH}$, as they flowed from the basin margin towards the centre of the basin (Parcerisa et al. 2005, 2006).

New data allow the conceptual models for fluid circulation within the basin to be extended. The fine-grained terrigenous sediments of the distal parts of the basin record two episodes of fluid migration. The first occurred prior to consolidation and lithification, during Burdigalian times, when shallow burial conditions allowed oxidizing meteoric waters to flow horizontally through porous and permeable sandy layers (Fig. 11Al). Development of clastic dykes created conduits for upward flow, allowing dewatering of the sand beds (Fig. 11A2). Liquefaction and expulsion of fluids were driven by seismic shaking. No cementation occurred during this first episode of fluid migration, probably because low fluid volumes were involved. The green colour of the clastic dykes could reflect reduction of $\mathrm{Fe}$ and Mn-oxyhydroxides in the matrix (Casas et al. 2003).

The second episode of fluid migration occurred synchronously with normal fault development. Cycles of rupture, fluid drainage and cement precipitation recorded by these faults implies that they acted as conduits for fluids during the syn-kinematic periods. The calcite cements in the normal faults show petrographic and geochemical similarities to the calcite cement in the sandstone of the upper detrital unit (Parcerisa et al. 2005). This suggests that fluids moved laterally as they cemented the sandstone layers, and also travelled vertically through the faults connecting the sandstone layers (Fig. 11B). The largest permeability in this normal fault setting was probably parallel to $\sigma_{2}$ along strike (Sibson 2000). When the faults became occluded by calcite-barite cement, shortly after fault development, they became barriers to vertical and horizontal fluid flow.

\section{CONCLUSIONS}

Two sets of fractures, developed during the extensional tectonic regime that created the Vallès-Penedès half-graben prior to the Messinian compression, occur in fine-grained terrigenous syn-rift sediments deposited in intermediate to distal parts of alluvial fans. The first set consists of small extension fractures infilled with mud and sands and the second consists of normal faults filled with calcite (and minor barite) cements.

The joints filled with mud and sands are attributed to seismically induced liquefaction and probably formed prior to consolidation and lithification, when shallow burial conditions allowed oxidizing meteoric waters to flow horizontally through porous and permeable sandy layers. Clastic dykes served as conduits for flow and dewatering of the sandy beds. Liquefaction and expulsion of fluids was probably driven by seismic shaking. During this first episode of fluid migration there was no cementation, probably because low fluid volumes were involved.

The normal faults are thought to be related to stress adjustments around the largest fault (the Vallès-Penedès normal fault). They may represent high-permeability horsetail extensional fracture meshs developed near the ground surface in the hanging walls of major normal faults (Sibson 2000). The incremental vein development indicates episodic changes in the tectonic stress state and fault zone permeability. Fluid circulation along the normal faults and precipitation of cements occurred synchronously with normal fault development, when the faults acted as fluid conduits. Fluid flow was lateral through the sandstone layers and dominantly vertical through the faults connecting separate sandstone layers.

Dissolution of manganese oxyhydroxides by a meteoric fluid under transitional redox potential is the most likely 
(A) Early after sedimentation (lower Burdigalian times)

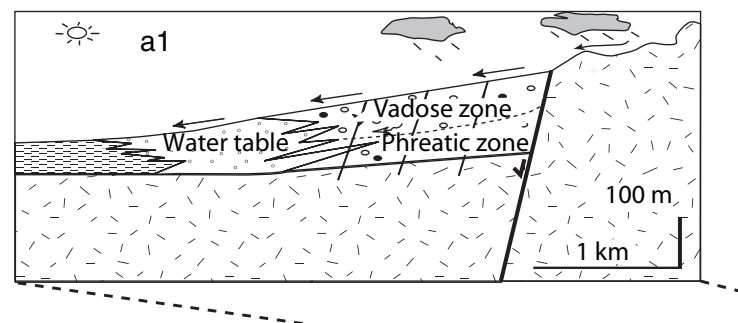

(B) Early after sedimentation (upper Burdigalian times)

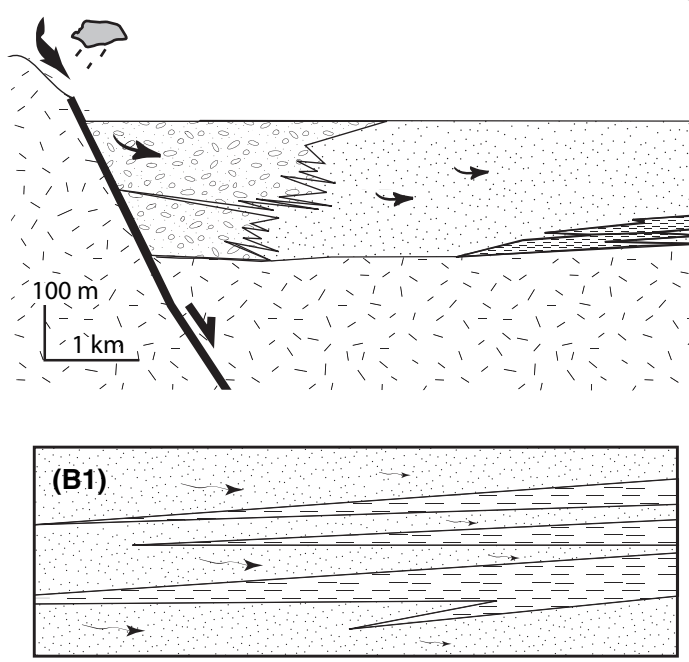

Horizontal fluid flow

Oxic meteoric fluids and shallow burial conditions

Compartments with different porosities and permeabilities
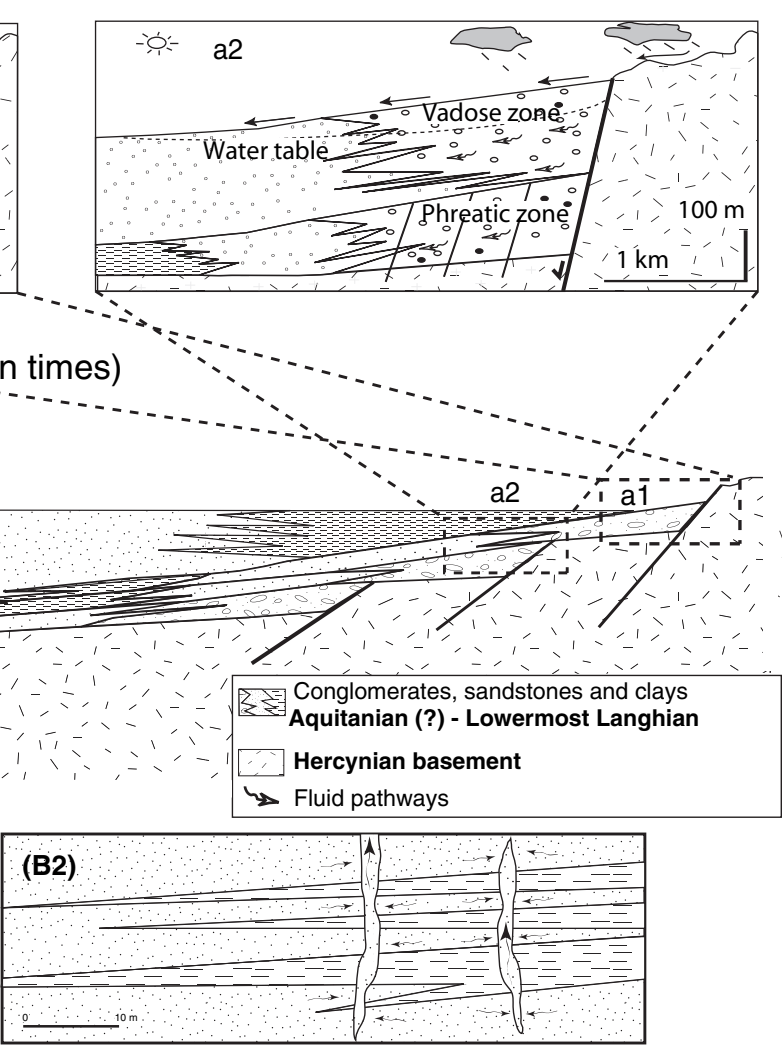

Clastic dykes development (seismites)

Upwards vertical fluid flow/dewatering of sand beds

Reduced meteoric fluids and deeper burialconditions

Conection between compartments

Low volume of fluid flow

(C) Normal fault development (prior to Messinian times)

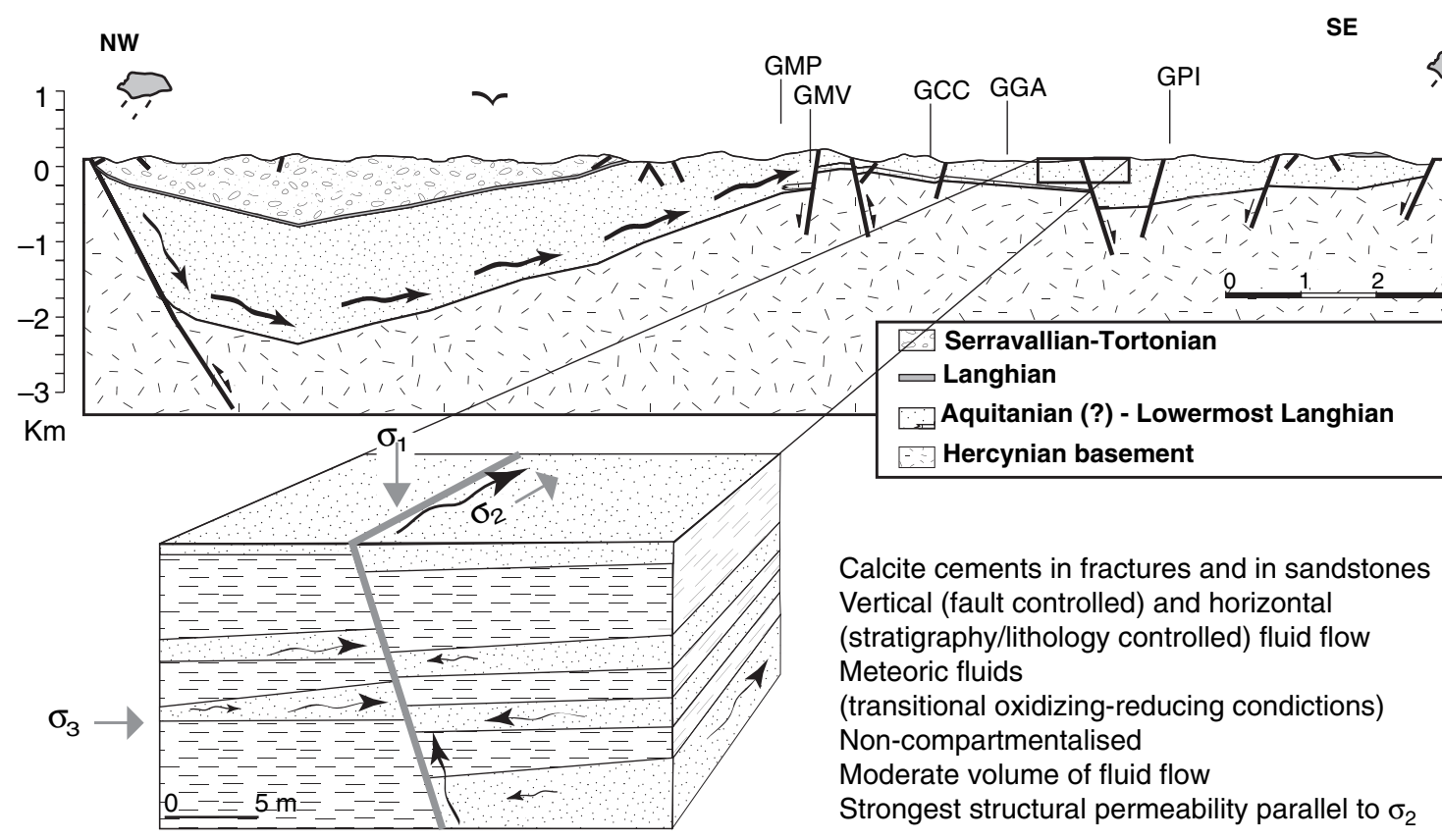

Fig. 11. Conceptual fluid-flow model for the Vallès-Penedès half-graben. 
origin of the high $\mathrm{Mn}^{2+}$ concentrations in the calcite cements. This fluid, characterized by a light $\delta^{18} \mathrm{O}$ composition, a negative and narrow range of $\delta^{13} \mathrm{C}$ values, high ${ }^{87} \mathrm{Sr} /{ }^{86} \mathrm{Sr}$ ratios, and a very high $\mathrm{Mn}^{2+}$ concentration, was responsible for vein calcite precipitation. The driving force for this diagenetic remobilization of $\mathrm{Mn}$ oxyhydroxides was probably bacterially mediated decomposition of organic material, which could have supplied large amounts of $\mathrm{Mn}^{2+}$ to the fluids. Transitional redox potentials were required for leaching $\mathrm{Mn}$-oxides but not Fe-oxides. This Mn-rich meteoric fluid migrated towards fractures, which represented the more permeable pathways in this setting of dominantly fine-grained sediments. In the fractures, small fluctuations in the Eh allowed precipitation of $\mathrm{Mn}$-bearing calcite cements, probably under water-saturated conditions during relatively shallow burial diagenesis.

The narrow range of $\delta^{13} \mathrm{C}$ values may reflect precipitation of calcite cements over a relatively narrow depth range within fractures that tapped only a small part of the carbon isotope reservoir. Alternatively, it may indicate that the $\delta^{13} \mathrm{C}$ value of the carbon reservoir did not change much with depth. The higher $\mathrm{Mn}$ content, lower $\delta^{18} \mathrm{O}$ and $\delta^{13} \mathrm{C}$ values, and lower ${ }^{87} \mathrm{Sr} /{ }^{86} \mathrm{Sr}$ ratio observed in more distal settings (Table 5) suggest that meteoric waters, which would have entered into the basin from the northern margin, interacted more extensively with the basin sediments as they moved southwards.

This study demonstrates the utility of petrological and geochemical studies of cementation to unravel the paleohydrology of rift basins. Although Vallès-Penedès basin is not a hydrocarbon-bearing basin, such methods can ultimately help to understand and evaluate hydrocarbons in rift basins.

\section{ACKNOWLEDGEMENTS}

This work is dedicated to the memory and honour of Professor Francesc Calvet who died during the course of this work. We thank R. Vaquer for discussion of some of the geochemical results, P. Labaume, H. Tsikos, V. Harcouet, M. Appold and two anonymous reviewers for their constructive comments on an earlier version of the manuscript. V. Harcouet, M. Appold and S. Ingebritsen are also thanked, together with Martha Lilly, for the accurate revision of the English version. The sulphur isotope analyses were carried out at 'Servicio General de Análisis de Isótopos Estables' of the Universidad de Salamanca and the oxygen and carbon isotope and electron microprobe analyses were carried out at 'Serveis Cientificotècnics' of the Universitat de Barcelona. This research was performed within the framework of DGICYT Spanish Project CGL2006-04860 and Grups Consolidats de Recerca 'Geologia Sedimentària' (2009SGR-1451).

\section{REFERENCES}

Agustí J, Cabrera L, Moyà-Solà S (1985) Sinopsis estratigráfica del Neógeno de la fosa del Vallès-Penedès. Paleontologia $i$ Evolució, $18,57-81$.

Antonellini M, Aydin A (1994) Effect of faulting on fluid flow in porous sandstone: petrophysical properties. American Association of Petroleum Geologists Bulletin, 78, 355-77.

Antonellini M, Aydin A (1995) Effect of faulting on fluid flow in porous sandstone: geometry and spatial distribution. American Association of Petroleum Geologists Bulletin, 79, 642-71.

Badley ME, Price JD, Rambech Dahl C, Agdestein T (1988) The structural evolution of the northern Viking Graben and its bearing upon extensional modes of basin formation. Journal of Geological Society of London Bulletin, 145, 455-72.

Barnaby RJ, Rimstidt JD (1989) Redox conditions of calcite cementation interpreted from $\mathrm{Mn}$ and Fe contents of authigenic calcites. Geological Society of America Bulletin, 101, 795-804.

Bartrina MT, Cabrera L, Jurado MJ, Guimerà J, Roca E (1992) Evolution of the central Catalan margin of the Valencia trough (Western Mediterranean). Tectonophysics, 203, 219-47.

Berner RA (1971) Principles of Chemical Sedimentology. McGrawHill Book Company, New York, 240 pp.

Berry LG, Mason B (1959) Mineralogy. W. H. Freeman \& Company, San Francisco, CA, 612 pp.

Bodine MW, Holland HD, Borcsik M (1965) Coprecipitation of manganese and strontium with calcite. In: Problems of Postmagmatic Ore Deposition - Symposium, Vol 2 (ed. Kutina J), pp. 401-6. Geological Survey of Czechoslovakia, Czechoslovak Academy of Sciences, Prague.

Boullier AM, Robert F (1992) Palaeoseismic events recorded in Archaean gold-quartz vein networks, Val d'Or, Abitibi, Quebec, Canada. Journal of Structural Geology, 14, 161-79.

Brockamp O (1976) Dissolution and transport of manganese by organic acids and their role in sedimentary $\mathrm{Mn}$ ore formation. Sedimentology, 23, 579-86.

Cabrera L, Calvet F (1996) Onshore Neogene record in NE Spain: Vallès-Penedès and El Camp half-grabens (NW Mediterranean). In: Tertiary Basins of Spain: The Stratigraphic Record of Crustal Kinematics (eds Friend PT, Dabrio C), pp. 97-105. Cambridge University Press, Cambridge.

Cabrera L, Calvet F, Guimerà J, Permanyer A (1991) El registro sedimentario miocénico en los semigrabens del Vallès-Penedès y de El Camp: Organización secuencial y relaciones tectónica sedimentación. I Congreso del Grupo Español del Terciario. (ed. Colombo F), Libro-Guia Excursión 4. University of Barcelona, Barcelona, $132 \mathrm{pp}$.

Casas Ll, Parcerisa D, Gómez-Gras D, Calvet F, Roig A, Molins E (2003) Mössbauer spectrometry to study diagenetical processes of red beds and sand dikes in the Vallès-Penedès half graben. Hyperfine Interactions (C), 5, 393-6.

Cerling TE (1984) The stable isotopic composition of modern soil carbonate and its relationship to climate. Earth and Planetary Science Letters, 71, 229-40.

Claypool GE, Kaplan IR (1974) The origin and distribution of methane in marine sediments. In: Natural Gases in Marine Sediments (ed. Kaplan IR), pp. 99-139. Plenum Press, New York.

Coleman ML, Moore MP (1978) Direct reduction of sulphate to sulphur dioxide for isotopic analysis. Analytical Chemistry, 50, 1594-5.

Craig H (1965) The measurements of oxygen isotope paleotemperatures. In: Stable Isotopes in Oceanographic Studies and Paleotemperatures (ed. Tongiorgi E), pp. 161-82. Consiglio Nazionale delle Richerche, Laboratorio di Geologia Nucleare, Pisa, Italy. 
Craig H, Gordon LI (1965) Deuterium and oxygen-18 variations in the ocean and marine atmosphere. In: Stable Isotopes in Oceanographic Studies and Paleotemperatures (ed. Tongiorgi E), pp. 9-130. Consiglio Nazionale delle Richerche, Laboratorio di Geologia Nucleare, Pisa, Italy.

Curtis CD (1978) Possible links between sandstone diagenesis and depth-related geochemical reactions occurring in enclosing mudstones. Journal of Geological Society of London Bulletin, 135, 107-17.

Curtis CD, Coleman ML, Love LG (1986) Pore water evolution during sediment burial from isotopic and mineral chemistry of calcite, dolomite and siderite concretions. Geochimica et Cosmochimica Acta, 50, 2321-34.

Dromgoole EL, Walter LM (1990) Iron and manganese incorporation into calcite: effects of growth kinetics, temperature, and solution chemistry. Chemical Geology, 81, 311-36.

Emery D (1987) Trace-element source and mobility during limestone burial diagenesis - an example from the Middle Jurassic of eastern England. In: Diagenesis of Sedimentary Sequences (ed. Marshall JD), Geological Society London Special Publication, 36, 201-17.

Fernàndez M, Banda E (1988) Aproximación a la anomalía geotérmica de La Garriga-Samalús (Vallès-Penedès). Acta Geológica Hispánica, 25, 75-81.

Gawthorpe RL (1987) Burial dolomitization and porosity development in a mixed carbonate-clastic sequence: an example from the Bowland Basin, northern England. Sedimentology, 34, 53358.

Hem JD (1964) Deposition and solubility of manganese oxides. US Geological Survey Water Supply Paper, 1667-B, 1-42.

Hendry JP (1993) Calcite cementation during bacterial manganese, iron and sulphate reduction in Jurassic shallow marine carbonates. Sedimentology, 40, 87-106.

Jonk R, Hurst A, Duranti D, Parnell J, Mazzini A, Fallick AE (2005) Origin and timing of sand injection, petroleum migration, and diagenesis in Tertiary reservoirs, south Viking Graben, North Sea. AAPG Bulletin, 89, 329-57.

Labaume P, Berty C, Laurent P (1991) Syn-digenetic evolution of shear structures in superficial nappes: an example from the Northern Apennines (NW Italy). Journal of Structural Geology, $13,385-98$

Labaume P, Kastner M, Travé A, Henry P (1997) Carbonate veins from the décollement zone at the toe of the northern Barbados accretionary prism (ODP Leg 156): microstructure, mineralogy, geochemistry and relationships with prisms structures and fluid regime. Proceedings of the Ocean Drilling Program, Scientific Results, 156, 79-96.

Labaume P, Carrio-Schaffhauser E, Gamond JF, Renard F (2004) Deformation mechanisms and fluid-driven mass transfers in the recent fault zones of the Corinth Rift (Greece). Comptes Rendus Geoscience, 336, 375-83.

Lee YJ, Wiltschko DV (2000) Fault controlled vein dilation: competition between slip and precipitation rates in the Austin Chalk, Texas. Journal of Structural Geology, 22, 1247-60.

Levi T, Weinberger R, Aifa T, Eyal Y, Marco S (2006) Earthquake-induced dikes detected by anisotropy of magnetic susceptibility. Geology, 34, 69-72.

Lorens RB (1981) Sr, Cd, Mn, and Co distribution coefficients in calcite as a function of calcite precipitation rate. Geochimica et Cosmochimica Acta, 45, 553-61.

Matthai SK, Aydin A, Pollard DD, Roberts SG (1998) Numerical simulation of departures from radial drawdown in a faulted sandstone reservoir with joints and deformation bands. In: Faulting, Fault Sealing and Fluid Flow in Hydrocarbon Reser- voirs (eds Jones G, Fisher QJ, Knipe RJ), Geological Society London Special Publication, 147, 157-91.

McIntire WL (1963) Trace element partition coefficients - a review of theory and applications to geology. Geochimica et Cosmochimica Acta, 27, 1209-64.

McKenzie DP (1978) Some remarks on the development of sedimentary basins. Earth and Planetary Science Letters, 18, 1-32.

Morad S, De Ros LF, Nystuen JP, Bergan M (1998) Carbonate diagenesis and porosity evolution in the sheet-flood sandstones: evidence form the Middle and Lower Lunde Members (Triassic) in the Snorre Field, Norwegian North Sea. In: Carbonate Cementation in Sandstones (ed. Morad S), pp. 53-85. Blackwell Science, Oxford.

Mount JF, Cohen AS (1984) Petrology and geochemistry of rhizoliths from Plio-Pleistocene fluvial and marginal lacustrine deposits, East Lake Turkana, Kenya. Journal of Sedimentary Petrology, 54, 263-75.

Mucci A (1988) Manganese uptake during calcite precipitation from seawater: conditions leading to the formation of a pseudokutnahorite. Geochimica et Cosmochimica Acta, 52, 1859-68.

Neaman A, Mouélé F, Trolard F, Bourrié G (2004) Improved methods for selective dissolution of $\mathrm{Mn}$ oxides: applications for studying trace element associations. Applied Geochemistry, 19, 973-9.

Niemi TM, Ferris AN, Abers GA (2004) Investigation of microearthquakes, macroseismic data, and liquefaction associated with the 1867 Wamego earthquake in Eastern Kansas. Bulletin of the Seismological Society of America, 94, 2317-29.

Obermeier SF (1996) Use of liquefaction-induced features for paleoseismic analysis. An overview of how seismic liquefaction features can be distinguished from other features and how their regional distribution and properties of source sediment can be used to infer the location and strength of Holocene paleo-earthquakes. Engineering Geology, 44, 1-76.

Ottesen Ellevset S, Knipe RJ, Svava Olsen T, Fisher QJ, Jones G (1998) Fault controlled communication in the Sleipner Vest Field, Norwegian Continental Shelf; detailed, quantitative input for reservoir simulation and well planning. In: Faulting, Fault Sealing and Fluid Flow in Hydrocarbon Reservoirs (eds Jones G, Fisher QJ, Knipe RJ), Geological Society London Special Publication, 147 283-97.

Parcerisa D (2002) Petrologia $i$ diagènesi en sediments de l'Oligocè superior $i$ del Miocè inferior $i$ mitjà de la Depressió del Vallès $i$ del Pla de Barcelona. Evolució de l'àrea font $i$ dinàmica dels fluids. PhD Thesis, Universitat Autònoma de Barcelona, Barcelona, 288 pp.

Parcerisa D, Gómez-Gras D, Travé A (2005) A model of early calcite cementation in alluvial fans: evidence from the Burdigalian sandstones and limestones of the Vallès-Penedès half-graben (NE Spain). Sedimentary Geology, 178, 197-217.

Parcerisa D, Gómez-Gras D, Travé A, Martin-Martin J (2006) Fe and $\mathrm{Mn}$ in calcites cementing red beds: a record of oxidationreduction conditions. Examples from the Catalan Coastal Ranges (NE Spain). Journal of Geochemical Exploration, 69-70, 177-82.

Parcerisa D, Gómez-Gras D, Roca E, Madurell J, Agustí J (2007) The Upper Oligocene of Montgat (Catalan Coastal Ranges, Spain): new age constrains to the western Mediterranean Basin opening. Geologica Acta, 5, 3-17.

Pedersen TF, Price NB (1982) The geochemistry of manganese carbonate in Panama Basin sediments. Geochimica et Cosmochimica Acta, 46, 59-68.

Pfeifer HR, Oberhänsli H, Epprecht W (1988) Geochemical evidence for a synsedimentary hydrothermal origin of Jurassic 
iron-manganese deposits at Gonzen (Sargans Helvetic Alps, Switzerland). Marine Geology, 84, 257-72.

Pingitore NE Jr (1978) The behavior of $\mathrm{Zn}^{++}$and $\mathrm{Mn}^{++}$during carbonate diagenesis: theory and applications. Journal of Sedimentary Petrology, 48, 799-814.

Pisciotto KA, Mahoney JJ (1981) Isotopic survey of diagenetic carbonates. Initial Reports of the Deep Sea Drilling Project, 63, 595-609.

Plata A (1994) Composición isotópica de las precipitaciones y aguas subterráneas de la Península Ibérica. Publicaciones del CEDEX, Madrid.

Polgári M, Okita PM, Hein JR (1991) Stable isotope evidence for the origin of the Urkut manganese ore deposit, Hungary. Journal of Sedimentary Petrology, 61, 384-93.

Pomerol B (1983) Geochemistry of the Late Cenomanian-Early Turonian chalks of the Paris Basin: manganese and carbon isotopes in carbonates as paleoceanographic indicators. Cretaceous Research, 4, 85-93.

Pratt LM, Force ER, Pomerol B (1991) Coupled manganese and carbon-isotopic events in marine carbonates at the CenomanianTuronian boundary. Journal of Sedimentary Petrology, 61, 37083.

Presley BJ, Kaplan IR (1968) Changes in dissolved sulphate, calcium and carbonate from interstitial water of near-shore sediments. Geochimica et cosmochimica Acta, 32, 1037-49.

Quinby-Hunt MS, Wilde P (1996) Chemical depositional environments of calcic marine black shales. Economic Geology, 91, 4-13.

Ramsay JG (1980) The crack-seal mechanism of rock deformation. Nature, 284, 135-9.

Redondo R, Yélamos JG (2000) Hidrogeoquímica convencional e isotópica de las aguas carbónicas de Cataluña. Geogaceta, 28, $121-4$.

Renard F, Andréani M, Boullier AM, Labaume P (2005) Crackseal patterns: records of uncorrelated stress release variations in crustal rocks. Geological Society, London, Special Publications, 243, 67-79.

Ritger S, Carson B, Suess E (1987) Methane-derived authigenic carbonates formed by subduction-induced pore-water expulsion along the Oregon/Washington margin. Geological Society of America Bulletin, 98, 147-56.

Robert F, Boullier AM, Firdaous K (1995) Gold-quartz veins in metamorphic terranes and their bearing on the role of fluids in faulting. Journal of Geophysical Research, 100, 12861-79.

Robinson BW, Kusakabe M (1975) Quantitative preparation of sulphur dioxide for ${ }^{34} \mathrm{~S} /{ }^{32} \mathrm{~S}$ analysis from sulphides by combustion with cuprous oxide. Analytical Chemistry, 47, 1179-81.

Roca E, Guimerà J (1992) The Neogene structure of the eastern Iberian margin: structural constraints on the crustal evolution of the Valencia Trough (Western Mediterranean). Tectonophysics, 203, 203-18.

Roca E, Sans M, Cabrera L, Marzo M (1999) Oligocene to Middle Miocene evolution of the Central Catalan margin (northwestern Mediterranean. Tectonophysics, 315, 209-29.

Russell MJ (1975) Lithogeochemical environment of the Tynagh base-metal deposits, Ireland, and its bearing on ore deposition.
Transactions of the Institute of Mining and Metallurgy, 84, B128-33.

Sample JC, Reid MR (1998) Contrasting hydrogeologic regimes along strike-slip and thrust faults in the Oregon convergent margin: evidence from the chemistry of syntectonic carbonate cements and veins. Geological Society of America Bulletin, 110, 48-59.

Schultz JL, Boles JR, Tilton GR (1989) Tracking calcium in the San Joaquin Basin, California: a strontium isotopic study of carbonate cements at North Coles Levee. Geochimica et Cosmochimica Acta, 53, 1991-9.

Secor DT (1965) Role of fluid pressure in jointing. American Journal of Sciences, 263, 633-46.

Sibson RH (2000) Fluid involvement in normal faulting. Journal of Geodynamics, 29, 469-99.

Smith AG (1996) Cenozoic latitudes, positions and topography of the Iberian Peninsula. In: Tertiary Basins of Spain: The Stratigraphic Record of Crustal Kinematics. World and Regional Geology 6 (eds Friend PF, Dabrio CJ), pp. 6-8. Cambridge University Press, Cambridge.

Suess E (1979) Mineral phases formed in anoxic sediments by microbial decomposition of organic matter. Geochimica et Cosmochimica Acta, 43, 339-52.

Tasse N, Hesse R (1984) Origin and significance of complex authigenic carbonates in Cretaceous black shales of the Western Alps. Journal of Sedimentary Petrology, 54, 1012-27.

Travé A, Calvet F (2001) Syn-rift geofluids in fractures related to the early-middle Miocene evolution of the Vallès-Penedès halfgraben (NE Spain). Tectonophysics, 336, 101-20.

Travé A, Calvet F, Soler A, Labaume P (1998) Fracturing and fluid migration during Paleogene compression and Neogene extension in the Catalan Coastal Ranges, Spain. Sedimentology, 45, 1063-82.

Tsikos H, Beukes NJ, Moore JM, Harris C (2003) Deposition, diagenesis, and secondary enrichment of metals in the Paloproterozoic Hotazel Iron Formation, Kalahari Manganese Field, South Africa. Economic Geology, 98, 1449-62.

Tucker ME, Wright VP (1990) Carbonate Sedimentology. Blackwell scientific publications, Oxford, $482 \mathrm{pp}$.

Utrilla R, Ortí F, Pierre C, Pueyo JJ (1991) Composición isotópica de las evaporitas terciarias continentales de la cuenca del Ebro: relación con los ambientes deposicionales. Revista de la Sociedad Geológica de España, 4, 353-60.

Utrilla R, Pierre C, Ortí F, Pueyo JJ (1992) Oxygen and sulphur isotope compositions as indicators of the origin of Mesozoic and Cenozoic evaporites from Spain. Chemical Geology (Isotope Geosciences Section), 102, 229-44.

Veizer J (1992) Depositional and diagenetic history of limestones: stable and radiogenic isotopes. In: Isotopic Signatures and Sedimentary Records. Lecture Notes in Earth Sciences 43 (eds Clauer N, Chaudhuri S), pp. 13-48. Springer-Verlag, Berlin.

Vrolijk P, Sheppard SMF (1991) Syntectonic carbonate veins from the Barbados accretionary prism (ODP Leg 110); record of palaeohydrology. Sedimentology, 38, 671-90. 